\title{
Capital and asset quality implications for bank resilience and performance in the light of NPLs' regulation: a focus on the Texas ratio
}

\author{
Giulio Velliscig ${ }^{1} \cdot J^{\prime}$ sanco Floreani ${ }^{1} \cdot$ Maurizio Polato $^{1}$ (B) \\ Accepted: 28 November 2021 / Published online: 11 January 2022 \\ (C) The Author(s), under exclusive licence to Springer Nature Limited 2021
}

\begin{abstract}
Based on a sample of 63 listed European banks, this paper investigates the relationship of capital and asset quality, in terms of provisioning and coverage policies, with bank risk and performance during the period 2005Q1-2018Q4. Our results point out different relationships between risk-based and non-risk-based measures of capital with bank risk and performance profiles. In particular, the information content of the leverage ratio appears to be merely related to the bank dimensional feature, whereas the total capital ratio shows a positive and statistically significant relationship with bank stability and is also negatively related to insolvency risk, thereby suggesting a crucial role for capital for the overall bank resilience. In addition, more capitalized banks are associated with higher bank performance. Regarding asset quality, hefty coverage and provisioning policies are generally associated with both lower bank resilience and performance. These results are relevant for disentangling the implications that the regulatory overhaul set out to address the NPLs issue is having on banking activity.
\end{abstract}

Keywords Capital $\cdot$ Asset quality $\cdot$ Provisioning $\cdot$ Coverage $\cdot$ Bank stability $\cdot$ Bank performance

\section{Introduction}

This paper delves into the relationship between capital and asset quality with bank risk and performance.

In particular, the regulatory overhaul implemented in the aftermath of the global financial crisis (GFC) to counter the rapid deterioration of European banks' credit portfolio, and erosion of their capital base, motivated us to focus on capital and provisioning policies to shed light and clarify the implications that the new regulatory framework may have on bank risk and performance.

The GFC caused indeed a significant deterioration in the credit portfolio of European banks (EBA, 2016) with the NPLs' stock surging to 900 billion euros at the end of 2016

Maurizio Polato

maurizio.polato@uniud.it

Giulio Velliscig

velliscig.giulio@spes.uniud.it

Josanco Floreani

josanco.floreani@uniud.it

1 Department of Economics and Statistics, University of Udine, Via Tomadini 30A, 33100 Udine, Italy and the NPL ratio jumping from about $3 \%$ in 2005 to more than $7 \%$ in 2016 [33].

The prompt intervention of European supervisors helped containing the spread of the issue as the NPL ratio of EU financial institutions decreased to 3\% in 2019 but the stock of NPLs still persisted at dangerous levels marking 600 billion euros in June 2019. In addition, the values of the NPL ratio vary heterogeneously across euro area members, from $0.9 \%$ of Luxembourg to $37.4 \%$ of Greece, therefore fuelling the policy debate about non-performing exposures [48].

Regarding the supervisory measures deployed to address the NPLs' issue, the ECB published in March 2017 a guidance on NPLs that sets out the measures, processes and best practices for banks to deal with NPLs. A year later, the ECB published the addendum that determines the supervisory expectations regarding the level of coverage on nonperforming exposures. In a nutshell, banks are expected to fully cover the new secured and unsecured non-performing exposures within seven and two years, respectively [47]. At the same time, the European Commission adopted a comprehensive package of measures that included common minimum coverage levels for newly originated loans which turn into non-performing. Finally, in April 2019, an amendment to the European capital regulatory framework required 
banks to hold a minimum coverage level. If this minimum is not reached by the institution, then the difference between the actual coverage and the minimum required should be deducted from CET 1 capital. Therefore, the minimum coverage acts as a "statutory prudential backstop" whose purpose is to make the risks associated with NPLs better reflected in the CET 1 capital ratios. The new regulatory framework is thus completed by the introduction of the accounting standard IFRS 9 in January 2018 that redesigned provisioning on a forward-looking approach based on the expected loss mechanism which forces banks to larger and timelier provisions.

The interlink between capital and provisioning policies in combating the NPLs' issue clearly emerges from this picture and is further summarized by the ECB in the Texas Ratio, namely the ratio of non-performing loans to the sum of loan loss reserves and tangible common equity, which has been formulated in the 1980s by the American banker Gerald Cassidy of RBC Capital Markets. The Texas ratio has been widely employed in the USA as an asset quality measure and has been further adopted in Europe by the ECB as a highlevel NPL metric in its asset quality assessments.

Policy measures aimed at increasing coverage ratios and their restored role as prudential and monitoring tools within supervisory assessments are supported by literature which identifies additional capital cushions and provisions as solutions able to tackle NPLs and enhance lending to the real economy [14, 49, 66].

Regarding the adverse implications of NPLs on banking activity, the literature points out the key role of the deterioration of the loan portfolio quality in explaining banks' lower stability $[36,56]$, lower profitability, as well as higher default probability [8, 32, 40, 59, 75].

As the long-lasting NPLs crisis would likely exacerbate again following the recent COVID-19 pandemic, it results therefore compelling to study the interlink between capital and provisioning policies with bank risk and performance in the light of the regulatory overhaul that interested NPLs so to draw conclusions on the possible implications for banking activity that managers are going to incur when complying with the new regulation and thereby warning policymakers about its potential spillovers.

We, therefore, contribute to the extensive literature on the relationship between capital and bank risk and performance $[3,5,20]$.

We also resume the investigations on the relationship between provisioning policies and bank risk and performance emphasizing the role of the Texas ratio, mostly uncovered in studies on European banks. Coverage ratios have indeed suffered from a lack of literature interest which we aim to fill in the light of their recent increasing policy relevance.
The empirical methodology we designed to address our objectives consists of a fixed effects panel data regression analysis, in line with similar studies [16, 20], and a deeper investigation of the effects of the crisis and bank size, as robustness test, as well as a quantile regression analysis, conducted on quarterly data for a sample of $63 \mathrm{EU}$ listed banks over the 2005-2018 period.

The rest of the paper is organized as follows: Sect. 2 discusses the relevant literature and develops the research hypotheses; Sect. 3 describes the sample and the methodology employed; Sect. 4 describes the results; Sect. 5 provides some robustness tests; and Sect. 6 concludes and infers some policy implications.

\section{Literature review}

The regulatory overhaul implemented in the aftermath of the financial and sovereign debt crises has focused its efforts towards enhancing the banking system resilience through channels that span from higher capital requirements to a framework to deal with non-performing loans (NPLs), to enhanced transparency and communication techniques, and finally to better crisis management frameworks.

Banks' capital structure and asset quality have been therefore deeply reviewed and investors have been provided with better tools to evaluate bank risk. Thus, scholars have seized the opportunity to delve into the implications that such changes may have in terms of bank risk and performance.

We start digging into the literature that investigates the effects of capital requirements on bank risk-taking behaviour.

Capital requirements are designed by regulation to provide both an adequate cushion of equity during recessive economic cycles and a mechanism to contain excessive risktaking, in order to prevent bank insolvency and safeguard the stability of the financial system $[39,82]$

The theoretical literature analysing the effects of capital requirements on bank risk-taking behaviour develops along three main streams: the moral hazard theory, the charter value theory and the capital buffer theory (see [61]). These theories allow for different specifications of the relationship between bank capital and bank risk which ultimately remains ambiguous.

Recent empirical studies provide contrasting results. Some works support indeed a positive relationship between bank capital and bank risk-taking [43, 62, 71, 84, 88], whereas others support the opposite [20, 31, 68]. In particular, a higher capital base incentivizes a better risk monitoring and screening by banks managers as it reduces bank liability and bailout expectations [37]. On the other hand, however, the TBTF bias may lead to bank managers' moral 
hazard that would increase risk-taking backed by deposit insurance and government bailouts [20].

The study conducted by Jokipii and Milne [62], in particular, allows us to bring out the performance dimension from the interlink between bank capital and bank risk. Findings point out that banks with small capital buffers adjust the required level faster than banks with higher capital buffers, raising capital and lowering risk. Conversely, banks with higher capital buffers adjust their capital levels slower and increase both capital and risk. As an implication, well-capitalized banks are flexible enough to expand risks for future growth whenever valuable opportunities materialize.

Moreover, Demirguc-Kunt et al. [37] find that high capital banks performed better than their smaller counterparts in terms of equity value during the crisis. Consistent with these results, the study conducted by Beltratti and Stulz [15] also finds that higher capital is associated with better stock market performance.

We further introduce to this framework the asset quality dimension which emerges from the set of accounting, regulatory and supervisory interventions deployed to address the burst of the NPLs' issue. One measure, in particular, seems able to reconcile asset quality with the interlink described so far between capital, risk-stability and performance. It is the Texas ratio, namely the ratio between the gross value of NPLs and the sum between loan loss reserves (LLR) and the available tangible common equity (TCE). It is considered by the ECB as a key performance indicator and provides information regarding the level of coverage of troubled loans whose impact on bank risk and performance we are ultimately interested in deepening.

The Texas ratio has piqued the interest of some scholars like Jesswein [60] and Siems [85]. The former considers it as a measure of potential bank failure that, despite its simplicity, offers interesting insights into banks' resilience. The latter corroborates these results assessing its consistency as bank failure predictor across banks of different US member states.

As the literature on the Texas ratio is scarce [50], we investigate the implications of coverage levels on troubled loans for bank risk and bank performance focusing on loan loss provisions ${ }^{1}$ instead. Literature on loan loss provisions hinges on three main hypotheses: the earnings management, the capital management and the signalling hypothesis.

Recent studies support the first two hypotheses as loan loss provisions have been used by banks during the crisis and post-crisis period by bank managers to reduce the variability of net profits over time and to avoid the costs related to the violation of capital requirements [80].

\footnotetext{
$\overline{1}$ See Olszak et al. [76] and Avignone et al. [9] as recent developments in the literature related to loan loss provisions.
}

Income smoothing can be used to improve the risk perception of a bank to regulators and to further stabilize the bank stock price by reducing earnings volatility [19]. Loan loss provisions can, instead, be used as capital management tool to improve capital ratios [65]. In addition, earnings management also suggests a positive relationship between loan loss provisions and insolvency risk as banks close to bankruptcy have incentives to misrepresent the reported earnings via adjustment to loan loss provisions. Furthermore, such negative relationship should also account for the negative impact of large and timelier provisions required by regulation which force banks to an unprofitable disposal of NPLs (Ciavoliello et al., 2016) which ultimately affects profits and capital therefore jeopardizing banks' stability and increasing its insolvency risk.

Implications for bank risk and bank performance emerge also from the stream investigating the signalling hypothesis. The positive relationship between loan loss provision and stock returns revealed by literature suggests that managers can use provisions to convey private information to the market regarding future earnings instead of future loan losses. In detail, additional loan loss provisions convey the message that the management is able to cope with an eventual negative shock to earnings [4]. Investors, therefore, can positively embrace news regarding an increase in loan loss provisions by considering it a signal of financial health rather than an anticipated deterioration of credit portfolio's future quality.

Under the premises of the signalling theory, an increase in loan loss provisions may reduce the perceived systematic risk; otherwise, if the theory does not hold, increasing loan loss provisions are related to poor portfolio quality, therefore increasing systematic risk [41].

Moreover, depending on the reported level of non-performing loans, greater loan-loss allowances are also associated with higher market-to-book ratios [12].

However, for signalling to be effective, severe costs have to be associated with its misuse. Thus, an ill-designed framework could potentially jeopardize signalling effectiveness. Literature, indeed, does not univocally support such hypothesis. In fact, some papers have failed to prove it $[4,90]$.

Deepening the risk dimension, Bushman and Williams [25] investigate the impact of delayed expected loan loss recognition on different forms of risk. The authors show that delayed expected loan loss recognition is associated with higher stock market illiquidity, higher correlations between bank-level illiquidity and aggregate banking sector illiquidity and returns during recessions. These risks combined with lower transparency increase equity financing costs and opportunities for banks to engage in risk-shifting, thereby jeopardizing both individual and systemic bank stability.

$\mathrm{We}$, therefore, state the following hypothesis:

Hypothesis 1: High provisions act as a signalling mechanism, hence increasing market transparency, reducing 
overall stock volatility and increasing financial performance. The alternative hypothesis to be tested are as follows:

Hypothesis 2a: High provisions leave room for increases in asset riskiness, hence increasing equity risk exposure and lowering banks' performance.

Hypothesis $2 \mathrm{~b}$ : There is an asymmetric response in equity risk exposure in the sense that large provision policies (or higher levels of coverage ratios) lead banks to increasing systematic risk relative to specific risk, hence harming banks' stability and default risk.

Hypothesis 3: Extensive loans provision policies (or higher coverage ratios) turn to increase banks' insolvency risk.

Hypothesis 4: A higher capital base reduces bank equity risk and improves financial performance.

Hypothesis 5: There is a positive (negative) association between the bank's capital base and its stability (insolvency risk).

\section{Data and methodology}

\section{The sample}

From Bloomberg, we selected listed banks, according to the Industry Classification Benchmark (ICB) criterium, located in Eastern and Western Europe. Then, we require the resulting banks to meet at least one of six filters we arbitrarily introduce to exclude less significant banks from the sample. We require banks to be: (1) directly supervised by the ECB, (2) subjected to Stress Test exercise, (3) subjected to Transparency Test, (4) Global Systemically Important Banks (G-SIBs), (5) Global Systemically important institutions (G-SIIs); (6) Other Systemically important institutions (O-SIIs). Finally, we rule out banks whose quarterly data were not available. The final sample consists of 63 banks, covering 22 European countries. We, then, proceed downloading consolidated on-balance sheet quarterly data for each bank over the period 2005Q1-2018Q4. Summary statistics of the sample are outlined in Table 1.

\section{Risk and performance proxy variables}

This paragraph describes the rationale behind the selection of the variables we deem appropriate to study the relationship between capital and asset quality with bank risk and performance.

\section{Risk variables}

We first consider equity risk and break it down along three different dimensions: idiosyncratic risk, systematic risk and total risk. Following the traditional CAPM, being the cost of capital function of the market-risk premium and firms' beta, the latter can be extrapolated by the sensitivity of the firm equity return with respect to the return of the market portfolio [57]:

$R_{e_{i, t}}=\alpha_{i}+\beta_{e_{i, t}} R_{m_{i, t}}+\varepsilon_{i, t}$

where $R_{e_{i t}}$ is the monthly equity stock return of bank I at time t, $R_{m_{i, t}, t}$ is the monthly return of the market portfolio represented by the Euro Stoxx 600 index, and $\varepsilon_{i, t}$ is the error term which represents the contribution to total risk in terms of the idiosyncratic component $[2,86]$. We do not apply multi-factor models as the Fama-French model because the literature which assesses bank equity return using this approach is significantly scant [89]. We use market equity beta $\beta_{e_{i, t}}$ as proxy of banks' systematic risk exposure.

Then, collecting monthly data from Bloomberg, we proxy equity total risk using the 30 days stock volatility, calculated as follows:

$30 d$ stock volatility $=\sqrt{\frac{1}{N} \sum_{t=1}^{n}\left(R_{i, t}-\mathrm{AVR}_{i}\right)^{2}}$

where 30d stock volatility is the standard deviation of equity return for bank $i, R_{i, t}$ is the monthly return for bank $i, \mathrm{AVR}_{i}$ is the average equity return for bank $i$, and $\mathrm{N}$ is the number of observations.

We then consider banks' financial stability measures and choose the Z-score, an accounting-based measure, as first variable. Proposed initially by Roy [83], the Z-score is a spread measure able to provide information regarding the stability of banks $[13,30,67]$. It is inversely related to bank insolvency risk. Indeed, it mirrors the level of standard deviations by which ROA has to deviate from its average value to suppress the Equity value of the bank [28].

$Z_{\text {score }}=\frac{\mathrm{ROA}+\mathrm{ETA}}{\sigma \mathrm{ROA}}$

where ROA is the return on assets, ETA is the Equity-toAsset ratio, and $\sigma R O A$ is the standard deviation of the return on assets. Given that the Z-score presents a high level of skewness, we use the natural logarithm of $Z$-score in line with Liu et al. (2013).

Finally, we include a market-based measure of bank stability. We employ the Merton's Distance to Default (DtD) as proxy variable able to assess bank stability [63]. DtD represents the difference between the market value of assets and the default point, divided by asset market value multiplied for assets' volatility. We gather from Bloomberg Professional Services the one-year default probability (PD). Then, we calculate the DtD by inverse cumulative distribution function of the PD. 
Table 1 The sample

\begin{tabular}{|c|c|c|c|}
\hline Bank & Country & Bank & Country \\
\hline Erste group AG & Austria & Siauliu Bankas AB & Lithuania \\
\hline Raiffeisen Bank Intertiol AG & Austria & ABN AMRO Group NV & Netherlands \\
\hline Dexia SA & Belgium & ING Groep NV & Netherlands \\
\hline KBC Group & Belgium & SpareBank $1 \mathrm{SMN}$ & Norway \\
\hline Zagrebacka Banka & Croatia & Sparebank 1 SR Bank ASA & Norway \\
\hline Hellenic Bank PLC & Cyprus & Bank Handlowy W Warszawie SA & Poland \\
\hline Komercni Banka AS & Czech Republic & Bank Polska Kasa Opieki SA & Poland \\
\hline Danske Bank & Denmark & PKO Bank Polski & Poland \\
\hline Sydbank DC & Denmark & m Bank S.A & Poland \\
\hline Jyske Bank & Denmark & Santander Bank Polska SA & Poland \\
\hline Nordea Bank Abp (Finland) & Finland & ING Bank Slaski SA & Poland \\
\hline BNP Paribas SA & France & Bank Millennium SA & Poland \\
\hline Credit Agricole SA & France & Banco Commercial Portugues SA & Portugal \\
\hline Societe Generale SA & France & Banco BPI SA & Portugal \\
\hline Aareal Bank AG & Germany & Nova Ljubljanska Banka dd & Slovenia \\
\hline Commerzbank AG & Germany & BBVA & Spain \\
\hline Deutsche Bank AG & Germany & Banco de Sabdell & Spain \\
\hline Alpha Bank AE & Greece & Banco Santander & Spain \\
\hline Eurobank Ergasias SA & Greece & Bankinter SA & Spain \\
\hline National Bank of Greece SA & Greece & Caixa Banka & Spain \\
\hline Piraeus Bank SA & Greece & Liberbank SA & Spain \\
\hline OTP Bank Nyrt & Hungary & Nordea Bank ABP (Sweden) & Sweden \\
\hline Banca Carige & Italy & Skandiviska Enskilda Banken AB & Sweden \\
\hline Banca Monte dei Paschi di Siena & Italy & Svenska Handelsbanken AB & Sweden \\
\hline Banca Popolare di Sondrio & Italy & Swedbank AB & Sweden \\
\hline Banco BPM & Italy & Credit Suisse Group & Switzerland \\
\hline BPER Banca & Italy & UBS Group AG & Switzerland \\
\hline Credito Emiliano & Italy & HSBC Holdings PLC & UK \\
\hline Intesa Sanpaolo & Italy & Lloyd Banking Group PLC & UK \\
\hline Mediobanca & Italy & Royal Bank of Scotland Group PLC & UK \\
\hline Unicredit Banca & Italy & Barclays PLC & UK \\
\hline UBI Banca & Italy & & \\
\hline
\end{tabular}

The table presents the banks covered in the study

In formal terms, according with Paltrinieri et al., [77]: considering DtD a standard normal distribution, $\mathrm{DtD} \sim N(0,1)$, the probability of default $\mathrm{PD}$ is: CDF $(-\mathrm{DtD}): \phi(-\mathrm{DD})=1-\phi(\mathrm{DtD})$

$\phi(\mathrm{DtD})=\frac{1}{2}\left\lfloor 1+\operatorname{erf}\left(\frac{\mathrm{DtD}}{\sqrt{2}}\right)\right\rfloor$

Using the Bloomberg one-year default probability (PD) and applying the inverse of the cumulative distribution function, we obtain the DtD:

$\mathrm{DtD}=\phi^{-1}(\mathrm{PD})=\sqrt{2} \operatorname{erf}^{-1}(2 \mathrm{PD}-1)$ with $\mathrm{PD} \in(0,1)$

\section{Performance variables}

We identify three different measures of performance, extensively used by literature, that we deem able to capture several declinations of the performance concept. We first pick the return on assets (ROA\%), an accounting measure which provides information about the profitability of banks. It's defined by the ratio between the net income and total assets [7]. In addition, following the concept of shareholder value creation in business [72], a firm creates value for its equity holders when the return on capital is greater than the opportunity cost; thus, following Fiordelisi (2006), we employ the economic value added (EVA, a measure of shareholder value creation largely diffused in the value-based management literature. It is defined by the surplus value created by the firm on its existent 
investments. According to Fraker [54], we calculate EVA with the following formula:

$\mathrm{EVA}_{t}=\mathrm{Nopat}_{t}-\left(k_{e_{t}} \cdot \mathrm{BV}_{t}\right)$

where Nopat represents the Net Operating Profit after Taxes of the bank, $\mathrm{k}_{\mathrm{e}}$ is the cost of equity, and BV is the Equity Book value of the bank.

Finally, we include the price-to-book ratio (P/B) as proxy variable which assesses bank performance in terms of market value created for shareholders. Indeed, the P/B ratio represents the ability of the firm to generate excess earnings in the future, from its current capital structure along its embedded future growth opportunities.

\section{Explanatory variables}

\section{Capital}

The literature that investigates the relationship between capital, risk and performance has provided mixed results. As highlighted in Sect. 2, while a first branch of the theory predicts that capital improves banks' survival probability, incentivizing credit monitoring, decreasing the moral hazard incentives and improving financial performance [68, 73], another branch of the literature demonstrates that capital requirements increase bank risk-taking incentives and shrink financial performance $[18,21]$. The question is therefore unresolved but still topical.

We use several measures for identifying the level of capitalization of banks. First, we consider the total capital ratio. This measure is the ratio of the sum between Tier1 and Tier2 to the risk-weighted assets. Moreover, given its crucial role within the Basel III framework, we further include the common leverage ratio which we measure as ratio of assets to equity.

\section{Asset quality}

Regarding asset quality, we deepen the role of coverage levels on troubled loans and their effects on bank risk and performance measures. As highlighted by our literature review and by our research hypotheses, coverage policies can be perceived by the market in different ways: as a signalling mechanism of prudential behaviour, thereby containing bank riskiness in line with the expectations of bank authorities (see ECB addendum), or as signal that banks expect higher losses from their loans portfolio thereby possibly increasing the level of bank riskiness. Thus, the first variable we account for is the Texas ratio [60] which determines the level of coverage on troubled loans. It is traditionally calculated considering the gross value of non-performing loans divided by the sum of the loan loss reserves (LLR) and the available tangible common equity (TCE). The level of LLR expresses, through an internal bank's estimation, the expected loss, that is the level of non-performing loans without a recovery value and already absorbed through write-downs. TCE, instead, provides the cushion to absorb the unexpected losses. In order to bring out the economic drivers of the Texas ratio and validate its influence within the regulatory framework for NPLs, we apply some basic transformations (see Appendix 1) to the baseline formula which results in the following equation:

Texas Ratio $=\frac{1}{w k(1-\mathrm{cr})+\mathrm{cr}\left(1+\mathrm{PD}_{\mathrm{PL}} \frac{\mathrm{PL}}{\mathrm{NPL}}\right)+\alpha}$

where $\mathrm{cr}$ is the coverage ratio of NPLs and provides an indication of the expected losses on the loan portfolio. The higher the coverage, the better the Texas ratio. $w k$ represents an exogenous factor which reflects regulation. All being equal, the higher the factor, the better the Texas ratio. $\mathrm{PD}_{\mathrm{PL}}$ is the probability that performing loans turn non-performing. All being equal, the higher the probability, the better the Texas ratio as loan loss reserves would be higher. $\alpha$ is the ratio of excess tangible capital to NPLs.

The breakdown of its economic drivers allows us for further considerations about the eventual side-effects underlying the implementation of the new regulatory framework on NPLs. A reduction in the stock of NPLs clearly improves the Texas ratio in compliance with regulatory requirements, but, usually, their book value is higher than the price that investors are willing to pay (Ciavoliello et al., 2016) which make their disposal unfavourable as it would cause a capital reduction. In addition, regulators should also account for the implications in terms of lower profits and capital generation ability that stem from rapid and massive provisioning despite their clear favourable impact on Texas ratio values.

The Addendum to the ECB Guidance to banks on NPLs expects that banks provide full coverage for the unsecured portion of new NPLs after 2 years at the latest and for the secured portion after 7 years at the latest. In short, the regulatory framework so defined requires banks to maintain a level of Texas ratio equal to one which represents the equilibrium level. The equilibrium is expressive of the fact that the gross value of NPLs is totally covered by capital and reserves. We, thus, run the following self-designed econometrical equation in order to estimate the residual term $\varepsilon_{i, t}$ (Texas ratio spreads), which represents a proxy of the departure from the equilibrium level (100\%), namely the limit beyond which the bank is in turmoil (i.e., the gross value of NPLs is higher than the sum between LLR and TCE).

$\frac{\mathrm{NPL}_{G_{i, t}}}{\mathrm{TA}_{i, t}}=\alpha_{i, t}+\beta_{1} \frac{\mathrm{LLR}_{i, t}}{\mathrm{TA}_{i, t}}+\beta_{2} \frac{\mathrm{TCE}_{i, t}}{\mathrm{TA}_{i, t}}+\varepsilon_{i, t}$ 
Moreover, we include the LLP ratio (LLP/GL\%). It assesses the cost of loans on total gross loans; it's a measure of trouble on loan portfolio. Higher levels of provisioning determine that a higher part of risk is already been accounted in the profit and loss statement. Finally, we consider the coverage ratio \%, which is the ratio between loan loss reserves and the gross value of non-performing loans. It represents the total amount of funds set aside by bank to cover the expected loss on its loan portfolio.

\section{Liquidity and funding structure}

We include two variables that gauge bank liquidity position and financial structure. Regarding the former, we picked the ratio between gross loans to short-term funding and deposits. According to Chiaramonte and Casu [29], its relationship with risk variables can be interpreted in different ways. If the market perceives negatively banks with a lower level of deposits and liquidity, this aspect leads to an increase in equity risk. Conversely, if the market favours banks with a higher level of loans for a given level of deposit, we expect a positive sign with bank performance variables and a negative sign between the ratio and the bank risk variables. As regards the measure of financial structure, we consider the ratio between short-term debt and total liabilities. Banks that are dependent on short-term debt are more vulnerable to liquidity shocks and subtend a higher level of risk. Thus, we expect a positive relationship with our risk variables and a negative one with performance measures.

\section{Control variables}

We also consider some control variables (CV) to strengthen the soundness of our results. We include the efficiency ratio \%, given by the ratio between operating expenses and total revenues. The literature shows as more efficient banks perform better than the others and exhibit a lower level of risk. We then include bank size as natural logarithm of total assets. Larger banks can benefit from economies of scale and portfolio diversification, improving financial performance and decreasing the risk exposures [78, 87]. As macro control variable widely diffused in the literature, we consider the variation rate of the gross domestic product ( $\Delta \% \mathrm{GDP})$. We expect positive variations of the gross domestic product to reduce the overall risk of banks' loans portfolio, hence lowering banks' default risk [59]. At the same time, we predict a positive relation between GDP\% growth rate and bank performance. Indeed, economic growth is traditionally linked to improvements of the loan portfolios, reducing the weight of loans loss provisions and increasing profitability [74].

To investigate our hypotheses, we employ, as baseline specification, a panel fixed effects methodology in line with the research design employed by Berger and Bouwman [16] and Bitar et al. [20]. The econometric equation results as follows.

$$
\begin{aligned}
& f(\text { Risk, Performance })_{i j t} \\
& =\alpha+\beta_{1} \cdot \text { Capital }_{i j t}+\beta_{2} \cdot \text { AssetQuality }_{i j t}+\beta_{3} \cdot \\
& \text { Liquidity_and_Funding_Structure }_{i j t}+\beta_{4} . \\
& \text { BankControls }_{i j t}+\gamma_{j}+\lambda_{t}+\varepsilon_{i j t}
\end{aligned}
$$

The dependent variables (Risk, Performance) refer to our risk and performance variables, as defined in Sect. 3.2., for bank $i$, in country $\mathrm{j}$, at time $\mathrm{t}$. The same applies to independent variables: capital, asset quality, liquidity and funding structure and bank controls, respectively. $\gamma_{j}$ captures the bank fixed effects which we include to gauge time-invariant unobservable bank traits. $\lambda_{t}$ captures instead the time fixed effects

Table 2 shows descriptive statistics of all variables included in our study. Table 3 reports pairwise correlation among explanatory variables. They are generally low, smaller than 0,4 , which is the limit above which the collinearity problem becomes more important (Kennedy, 1985).

\section{Baseline results}

Table 4 reports the result for the fixed effects panel data regression analysis based on Eq. (9).

\section{Risk results}

Idiosyncratic risk [1]: Model 1 does not report any significant relationship between our capital or asset quality variables and idiosyncratic risk.

We find a negative and significant relationship between our liquidity measure and idiosyncratic risk. Since the sample consists essentially of commercial banks, it is plausible to affirm that the market perceives positively banks with a higher level of loans for a given value of deposits as it expresses a greater focus on their core business [29].

Contrary to our expectations, we find a negative and statistically significant relationship between our measure of funding structure and idiosyncratic risk. To explain this result, we rely on the study of Du and Palia [44] which suggests that the market perceives as positive the ability of a bank to sustain a funding structure unbalanced towards short-term debt.

Finally, we report a positive and statistically significant relationship between bank size and idiosyncratic risk which we suggest may be due to the too-big-too-fail (TBTF) bias, that persists although the overhaul of resolution regulation, 
Table 2 Descriptive statistics of the variables

\begin{tabular}{|c|c|c|c|c|c|c|c|c|}
\hline & & & $\mathrm{N}$ & SD & mean & $\mathrm{p} 25$ & $\mathrm{p} 50$ & p75 \\
\hline \multirow[t]{8}{*}{ Dependent Variables } & \multirow[t]{5}{*}{ Risk } & Idiosyncratic risk & 3107 & 0.737 & 0.428 & 0.029 & 0.138 & 0.442 \\
\hline & & Systematic risk ( $($ ) & 3288 & 1.057 & 1.347 & 0.821 & 1.270 & 1.714 \\
\hline & & 30d stock volatility & 3111 & 0.184 & 0.397 & 0.282 & 0.360 & 0.474 \\
\hline & & Ln (Z-score) & 3203 & 1.183 & 4.645 & 3.973 & 4.750 & 5.438 \\
\hline & & Distance to Default & 3373 & 0.479 & 2.840 & 2.526 & 2.828 & 3.163 \\
\hline & \multirow[t]{3}{*}{ Perf } & EVA & 3227 & 763.377 & 21.128 & -132.386 & 30.977 & 194.399 \\
\hline & & ROA\% & 3218 & 1.191 & 0.477 & 0.173 & 0.493 & 0.955 \\
\hline & & $\mathrm{P} / \mathrm{BR}$ & 3279 & 0.815 & 1.190 & 0.621 & 0.978 & 1.594 \\
\hline \multirow[t]{10}{*}{ Explanatory variables } & \multirow[t]{2}{*}{ Cap } & Total Capital ratio\% & 3232 & 4.029 & 14.766 & 11.800 & 14.245 & 17.000 \\
\hline & & Leverage (A/E) & 3357 & 69.361 & 13.460 & 11.356 & 15.547 & 21.011 \\
\hline & \multirow[t]{3}{*}{$\mathrm{Aq}$} & Texas ratio spread $\%$ & 3007 & 0.026 & 0.000 & -0.010 & -0.001 & 0.004 \\
\hline & & Loan Loss Provisions ratio\% & 3196 & 0.004 & 0.002 & 0.001 & 0.001 & 0.003 \\
\hline & & Coverage ratio $\%$ & 3000 & 0.615 & 0.763 & 0.485 & 0.621 & 0.776 \\
\hline & \multirow[t]{2}{*}{$\begin{array}{l}\text { Liq. e Fin. } \\
\text { Structure }\end{array}$} & $\begin{array}{l}\text { [Gross Loans/ (Short-term funding and } \\
\text { Deposits)] \% }\end{array}$ & 3327 & 0.472 & 1.015 & 0.771 & 0.925 & 1.197 \\
\hline & & (Short-Term Debt/Total Liabilities) \% & 3336 & 0.105 & 0.139 & 0.063 & 0.114 & 0.192 \\
\hline & \multirow[t]{3}{*}{$\mathrm{CV}$} & Efficiency ratio\% & 3315 & 65.409 & 62.796 & 50.877 & 58.727 & 68.554 \\
\hline & & Ln (TA) & 3336 & 1.717 & 12.300 & 11.059 & 12.045 & 13.724 \\
\hline & & $\operatorname{Var} \%$ GDP & 3465 & 0.151 & -0.008 & -0.035 & 0.014 & 0.052 \\
\hline
\end{tabular}

This table shows the descriptive statistics of the variables selected in our study. Risk variables are estimated following formulas from (1) to (5). EVA is estimated following formula (6). ROA is the ratio between net income and total assets. P/BR is the ratio between stock price and book value of shares. Total Capital ratio\% is the ratio between Total Capital (Tier 1+ Tier 2) and Risk-weighted assets. Leverage is the ratio between Total Asset and Total Equity. Texas ratio spreads are calculated following formula (7). The Loan Loss provisions ratio is the ratio between LLP and gross loans. Coverage ratio is the ratio between loan loss reserves and non-performing loans. Efficiency ratio is the ratio between operating expenses and total revenues. LN(TA) is the natural logarithm of total assets. Var\% GDP is the percentage variation of the GDP

Table 3 Correlation matrix

\begin{tabular}{lllllllllll}
\hline & TCR & LEV & TXR & LLPGL & COV & GLSTD & SHORT & EFF & InTA & GDP \\
\hline TCR & 1 & & & & & & & & & \\
LEV & 0.0575 & 1 & & & & & & & & \\
TXR & -0.0547 & -0.0042 & 1 & & & & & & & \\
LLPGL & -0.2105 & -0.0104 & 0.2085 & 1 & & & & & & \\
COV & -0.1407 & -0.0544 & -0.3825 & -0.0858 & 1 & & & & & \\
GLSTD & 0.0616 & -0.0492 & 0.0682 & -0.1097 & 0.1709 & 1 & & & & \\
SHORT & -0.2838 & -0.026 & 0.1575 & 0.1923 & -0.0647 & -0.2349 & 1 & & & \\
EFF & 0.0431 & 0.0854 & 0.043 & -0.0784 & -0.0439 & 0.0107 & -0.0287 & 1 & & \\
lnTA & 0.3002 & 0.0364 & -0.0517 & -0.1659 & -0.0927 & -0.0031 & 0.003 & 0.0217 & 1 & \\
GDP & -0.1085 & -0.0029 & 0.0187 & 0.04 & -0.0034 & -0.0082 & 0.0173 & 0.0159 & -0.021 & 1 \\
\hline
\end{tabular}

This table shows the pairwise correlations among explanatory variables

which grants latitude to larger banks as regards engaging into excessive risk-taking.

Equity betas [2]: Regarding equity betas, Model 2 points out a positive and statistically significant relationship between both the Texas ratio spread and the LLP ratio with systematic risk. Higher Texas ratio spreads, indeed, increase equity betas as they signal inadequate coverage policies. Similarly, higher LLP ratios are symptomatic of a poor loan portfolio quality which explain their positive relationship with equity betas [41].

Regarding control variables, we point out a negative and statistically significant relationship between bank size and systematic risk which literature explains by mean of the scale competitive advantage that large banks have over smaller ones, and by their higher diversification and implicit government guarantee due to their TBTF status [41]. 
Table 4 Baseline regression

\begin{tabular}{|c|c|c|c|c|c|c|c|c|}
\hline & \multicolumn{4}{|l|}{ Risk } & \multicolumn{4}{|l|}{ Performance } \\
\hline & {$[1]$} & {$[2]$} & {$[3]$} & {$[4]$} & [5] & {$[6]$} & [7] & [8] \\
\hline TCR & $0.020(0.021)$ & $0.004(0.029)$ & $\begin{array}{c}-0.075 * * * \\
(0.025)\end{array}$ & $\begin{array}{r}0.206^{* * * *} \\
(0.036)\end{array}$ & $\begin{array}{r}0.231 * * * \\
(0.022)\end{array}$ & $\begin{array}{r}0.080 * * * \\
(0.031)\end{array}$ & $\begin{array}{r}0.273 * * * \\
(0.055)\end{array}$ & $\begin{array}{r}0.197 * * * \\
(0.016)\end{array}$ \\
\hline LEV & $\begin{array}{r}-0.047^{*} \\
(0.027)\end{array}$ & $0.038(0.066)$ & $\begin{array}{c}-0.032 * * * \\
(0.011)\end{array}$ & $\begin{array}{r}-0.872 \\
(0.917)\end{array}$ & $\begin{array}{c}-0.017 * * \\
(0.007)\end{array}$ & $0.057(0.084)$ & $0.032(0.020)$ & $-0.010(0.007)$ \\
\hline TXR & $\begin{array}{r}0.063 * * \\
(0.028)\end{array}$ & $\begin{array}{r}0.068 * * * * \\
(0.021)\end{array}$ & $0.053(0.038)$ & $\begin{array}{c}-0.123 * * * \\
(0.025)\end{array}$ & $\begin{array}{c}-0.103 * * * \\
(0.023)\end{array}$ & $\begin{array}{c}-0.020 \\
(0.013)\end{array}$ & $0.066(0.046)$ & $-0.006(0.013)$ \\
\hline LLPGL & $0.011(0.019)$ & $\begin{array}{r}0.076^{* * * *} \\
(0.022)\end{array}$ & $\begin{array}{r}0.110 * * * \\
(0.020)\end{array}$ & $\begin{array}{c}-0.275^{* * *} * \\
(0.028)\end{array}$ & $\begin{array}{c}-0.203 * * * \\
(0.020)\end{array}$ & $\begin{array}{r}0.179 * * * \\
(0.027)\end{array}$ & $\begin{array}{c}-0.320 * * * \\
(0.032)\end{array}$ & $\begin{array}{c}-0.108 * * * \\
(0.011)\end{array}$ \\
\hline $\mathrm{COV}$ & $\begin{array}{r}-0.001 \\
(0.014)\end{array}$ & $0.050 *(0.027)$ & $\begin{array}{r}0.032 * * \\
\quad(0.013)\end{array}$ & $\begin{array}{c}-0.071 * * * \\
(0.022)\end{array}$ & $\begin{array}{r}-0.008 \\
(0.014)\end{array}$ & $\begin{array}{c}-0.067 * * * \\
(0.016)\end{array}$ & $\begin{array}{r}-0.032 * \\
(0.014)\end{array}$ & $0.007(0.011)$ \\
\hline GRLSTD & $\begin{array}{c}-0.080 * * * \\
(0.024)\end{array}$ & $\begin{array}{r}-0.116^{*} \\
(0.062)\end{array}$ & $\begin{array}{r}0.160 * * * \\
(0.015)\end{array}$ & $\begin{array}{c}-0.016 \\
(0.025)\end{array}$ & $\begin{array}{c}-0.106^{* * *} * \\
(0.011)\end{array}$ & $0.016(0.015)$ & $\begin{array}{c}-0.072 * * * \\
(0.019)\end{array}$ & $\begin{array}{c}-0.085^{* * * *} \\
(0.010)\end{array}$ \\
\hline SHORT & $\begin{array}{c}-0.061 * * * \\
(0.020)\end{array}$ & $\begin{array}{r}0.067 * * \\
(0.029)\end{array}$ & $\begin{array}{r}0.130 * * * \\
(0.028)\end{array}$ & $\begin{array}{r}-0.055^{*} \\
(0.030)\end{array}$ & $\begin{array}{c}-0.239 * * * \\
(0.020)\end{array}$ & $\begin{array}{c}-0.001 \\
(0.020)\end{array}$ & $\begin{array}{c}-0.255^{* * *} * \\
(0.036)\end{array}$ & $\begin{array}{c}-0.092^{* * *} \\
(0.014)\end{array}$ \\
\hline $\mathrm{EFF}$ & $0.016(0.010)$ & $\begin{array}{c}-0.045 \\
(0.028)\end{array}$ & $0.000(0.022)$ & $\begin{array}{r}-0.050 * \\
(0.026)\end{array}$ & $\begin{array}{c}-0.001 \\
(0.014)\end{array}$ & $\begin{array}{c}-0.073^{* *} \\
(0.031)\end{array}$ & $\begin{array}{c}-0.002 \\
(0.064)\end{array}$ & $-0.007(0.008)$ \\
\hline LnTA & $\begin{array}{r}0.728 * * * \\
(0.111)\end{array}$ & $\begin{array}{c}-1.472 * * * \\
(0.259)\end{array}$ & $\begin{array}{c}-1.553 * * * \\
(0.121)\end{array}$ & $\begin{array}{r}0.416^{* * * *} \\
(0.156)\end{array}$ & $0.014(0.098)$ & $\begin{array}{r}0.615^{* * * *} \\
(0.136)\end{array}$ & $0.207 *(0.110)$ & $\begin{array}{c}-0.328 * * * \\
(0.089)\end{array}$ \\
\hline GDP & $\begin{array}{c}-0.051 \\
(0.045)\end{array}$ & $0.031(0.115)$ & $0.051(0.044)$ & $0.037(0.050)$ & $0.025(0.033)$ & $\begin{array}{r}-0.053 \\
(0.051)\end{array}$ & $\begin{array}{r}-0.006 \\
(0.047)\end{array}$ & $0.069(0.029)$ \\
\hline Cons & -0.096 & 0.221 & 0.273 & 0.000 & -0.094 & -0.044 & -0.087 & -0.069 \\
\hline Obs & 2580 & 2765 & 2657 & 2765 & 2835 & 2747 & 2820 & 2821 \\
\hline r-sq & $\begin{array}{l}0.6544 \\
(0.0000)\end{array}$ & $\begin{array}{l}0.3417 \\
(0.0000)\end{array}$ & $\begin{array}{l}0.7078 \\
(0.0000)\end{array}$ & $\begin{array}{l}0.4482 \\
(0.0000)\end{array}$ & $\begin{array}{l}0.7314 \\
(0.0000)\end{array}$ & $\begin{array}{l}0.4883 \\
(0.0000)\end{array}$ & $\begin{array}{l}0.5044 \\
(0.0000)\end{array}$ & $0.8089(0.0000)$ \\
\hline
\end{tabular}

This table reports the result for the fixed effects panel data regression analysis based on Eq. (9). The dependent variables are: [1] Idiosyncratic risk; [2] Equity beta; [3]30d Stock Volatility; [4] Ln(Z-score); [5] Distance to default; [6] EVA; [7] ROA; [8]PBR. *, ** and *** indicate statistical significance at the 10\%, $\% 5$ and $1 \%$ levels, respectively. Robust standard errors are shown in brackets

Total Risk (30d stock volatility) [3]: Model 3 shows a positive and statistically significant relationship between the LLP ratio and equity volatility. Higher levels of provisioning signal, indeed, either a poor portfolio quality or an incorrect level of coverage on the loan portfolio which negatively affects the market risk perception. The role of Texas ratio spread is not significant, meaning that the level of deviation from $100 \%$ level has no impact on banks' stock volatility.

As regards capital variables, we find a negative and statistically significant relationship between bank book leverage and equity volatility, contrary to the traditional hypothesis that more leveraged banks express more equity risk. A first explanation of this result is that the book leverage ratio probably is perceived only as a measure of dimension of the firm, expressing less information than the market leverage ratio [58]. In other words, if the book leverage is perceived externally only as a size measure, more "book" leveraged banks might be appreciated by the market. An alternative explanation of this result is consistent with the empirical findings of Haq and Heaney [57]: the constant deleveraging of banks, carried out by institutions in order to be compliant with Basel III capital requirements, makes the impact of the additional capital buffer on equity risk positive [14], thereby for more capitalized banks an increase in capital might subtend a more aggressive and riskier strategy which leads to less safe investments.

Regarding the total capital ratio, its relationship with equity volatility is negative and statistically significant coherently with the fact that higher capital levels reduce the probability of violating the threshold of the minimum capital requirement therefore entailing a positive impact on equity risk.

As regards control variables, our liquidity measure shows a positive and statistically significant relationship with equity volatility in line with the findings of Chiaramonte and Casu [29] which suggest a negative reaction of the market to low levels of deposits and liquidity. The same relationship emerges between our funding structure variable and equity risk in line with our expectations that predicted a higher vulnerability to liquidity shocks caused by a strong reliance on short-term debt.

Finally, size shows a negative and statistically significant relationship with equity volatility that may be explained by 
the TBTF bias implications for banks' risk as the implicit government guarantees reduce equity volatility.

Banks stability and default risk (Z-Score-Distance to Default) [4,5]: in Models 4 and 5 we put in the spotlight bank stability, measured by Z-Score, and default risk, measured by the distance to default. Among our capital variables, the leverage ratio does not show any predictive power, whereas the total capital ratio shows a positive and statistically significant relationship with both bank stability and distance to default. This result strengthens the idea that the book leverage ratio, from a financial stability point of view, is reflected as insignificant, subtending a lower information content. Conversely, a crucial role is played by the risk-based capital measure which improves banks' stability and reduces banks' insolvency risk.

As regards asset quality variables, we find a negative and statistically significant relationship between the LLP ratio and both the Z-score and the distance to default. An increase in the level of loans loss provisions is, indeed, perceived as an assumption of an incorrect level of coverage on banks' loan portfolios, therefore resulting in lower levels of stability and higher levels of default risk $[1,75]$. Similarly, the Texas ratio spreads assume significant explanatory power in both models 4 and 5, suggesting that a significative positive deviation from the equilibrium level increases the instability of the bank as well as the insolvency risk subtended by Merton's distance to default. In a similar vein, also the coverage ratio shows a negative and statistically significant relationship with the Z-score. It is, indeed, possible that higher levels of the coverage ratio may be perceived by the market as a signal of inadequate coverage policies. A further explanation stems from the implications posed by massive provisioning policies to profitability and capital generation ability as exposed in Sect. 3.1.1.

As regards control variables, Model 4 highlights the positive and statistically significant relationship between size and the Z-score which is again explained by the premises of TBTF theory as the larger the bank, the higher the probability to be rescued by the government in case of crisis. Regarding Model 5, instead, the ratio between short-term funding and total liabilities shows a negative and statistically significant relationship with the distance to default. Consistently with the relationship highlighted in model 3 when considering equity volatility, the market perceives those banks which heavily rely on short-term debt as riskier, unstable due to their vulnerability to liquidity shocks as widely confirmed in the literature (Diamon and Dybvig, 1983; Bernanke, 2008; Brunnermeier and Oehmke, 2013; Du and Palia, 2018). Finally, we point out a negative and statistically significant relationship between our liquidity measure and the distance to default. Again, consistently with results obtained in Model 3 when considering the impact on equity volatility, the market does not consider healthy low levels of deposits and liquidity which end up to increase default risk.

\section{Performance results}

Economic Value Added [6]: our results show a positive and statistically significant relationship between bank leverage and EVA. This is consistent with the idea that banks increase EVA lowering the level of capital, thereby increasing bank leverage and consequently bank business risk. The other variables do not assume statistical significance in the explanation of the EVA.

Model 6 shows a positive and statistically significant relationship between EVA and the total capital ratio in line with the branch of literature claiming that capital provides information about the ability of the bank to withstand liquidity crisis and abide by regulatory capital prescriptions therefore suggesting a positive relationship with profitability.

About asset quality variables, our results further point out a positive and statistically significant relationship between EVA and the LLP ratio in line with the literature' stand suggesting that higher loan loss provisions may convey to the market information about future earnings, instead of future losses, thus implying a healthy financial status that suggests the positive relationship with profitability. However, this explanation is confuted by the negative and statistically significant relationship between EVA and the coverage ratio which supports the more conservative view about the information that provisioning gives to the market.

About control variables, size is positively and significantly related to the EVA given the economies of scale that larger banks can harness to decrease the unit product cost and increase the profit rate [79].

ROA\% and price-to-book ratio [7,8]: The total capital ratio has a positive impact on bank profitability and market value. This result is consistent with Goddard et al., [55], Lee and Hsieh, [69] and Tan, [87], suggesting that more severe capital ratios improve risk management which consequently boosts bank profits as managers strive to be compliant with the regulatory framework. The book leverage, instead, is not significant.

Moreover, we confirm the results of Athanasoglou et al. [7] showing a negative relationship between the LLP ratio and bank profitability: higher levels of loan loss provisions, indeed, shrink banks profitability. The LLP ratio further shows a negative and statistically significant relationship with the P/BV ratio. Texas ratio spreads are instead insignificant.

The short-term debt-to-total liabilities ratio shows a negative and statistically significant relationship with bank profitability in Model 7. The more the bank is dependent on shortterm debt, the lower is the profitability as highlighted by Demirguc-Kunt and Huizinga (2009). The same relationship 
holds in Model 8 for the P/BV ratio: banks predominantly financed with short-term funding perform worse in terms of stock price and subtend a lower level of growth opportunities perceived by the market [15].

Our liquidity variable presents a negative and statistically significant relationship with the $\mathrm{P} / \mathrm{BV}$ ratio, suggesting that banks more focused on the traditional loan business are perceived riskier by the market, showing a higher level of stock volatility (Model 3), insolvency risk (Model 5), as well as a lower level of market value (Model 8). A possible explanation of this result stems from the burst of the NPL phenomenon which depressed the quality of loan portfolios of commercial banks, traditionally focused on the loans business, forcing them to extensive provisions policies and requiring additional capital buffer to cover loans losses.

About control variables, size shows a negative and statistically significant relationship with PBV in Model 8, in line with recent studies [22], as larger banks are generally valued less than their smaller peers on average.

In the light of our results, we do not find confirmation about hypothesis 1 . Provisions, proxied by the LLP ratio, show a positive and statistically significant relationship with equity volatility that does not validate the signalling hypothesis. Still, in its quality of LLP ratio, provisions appear to negatively affect bank performance in both its proxies of profitability and market value.

As a result, we corroborate hypothesis 2a showing that high provisions are associated with high equity risk exposure and low performance.

We also corroborate hypothesis $2 b$. Our results, indeed, support an asymmetric response in terms of idiosyncratic and systematic risk to provisions policies as either the LLP ratio and the Texas ratio spread are positively related to systematic risk but do not appear to significantly affect idiosyncratic risk. In addition, large provisions, in both their specifications of LLP ratio and Texas ratio spread, are proved to undermine bank stability.

Hypothesis 3 is confirmed. High provisions, in terms of LLP ratio, are, indeed, associated with high insolvency risk and lower stability. Higher coverage ratios appear, instead, only to be associated with lower levels of stability but are not significantly related with insolvency risk.

Regarding the role of capital, we confirm hypotheses 4 and 5. We, indeed, provide evidence of a negative and statistically significant relationship between the total capital ratio and equity volatility, whereas we point out a positive and statistically significant relationship between the same ratio and all the performance variables which supports hypothesis 4 . Regarding hypothesis 5 , we find a positive and statistically significant relationship between the total capital ratio and both the Z-score and the distance to default which supports our thesis of higher capital being associated with higher banks stability and lower insolvency risk.
The book leverage ratio, instead, is only significantly related to equity volatility but fails to explain all the performance variables therefore failing to find a position within the framework designed by our hypothesis.

\section{Robustness checks}

In this section, we provide a battery of additional tests to check for the consistency of our baseline results and dig deeper into their nature. We, first, rerun our baseline model over the crisis period to check for the evolution of the relationships considered during this time frame. As crisis period we consider the time frame between the last quarter of 2008 and the last quarter of 2012 so to account for both the subprime crisis and the sovereign debt crisis. We, then, discriminate between large and small banks to gauge the impact of banks size on the relationships considered by our framework. We, therefore, rerun the baseline model differentiating between above and below the median value of bank total assets. Finally, we run a quantile regression to gauge the behaviour of the relationships we consider across the percentiles of the distribution.

We start considering the crisis period to check whether the relationships outlined in the baseline model change during the crisis. The results of the test are presented in Table 5.

The relationship between book leverage and stock volatility remains negative, corroborating the hypothesis that the book leverage of banks is probably perceived externally as a dimension factor. Furthermore, when we focus on our accounting stability measure, the relationship between leverage and Z-Score is negative. It follows that more leveraged banks subtended during the crisis period a lower level of stability. This result is further corroborated by the negative and statistically significant relationship between leverage and the distance to default. As a result, the leverage ratio does not appear to play a marginal role from a financial stability point of view in contrast with baseline results.

Considering our risk-based capital measure, the negative and statistically significant relationship with equity volatility outlined in the baseline model does not hold. Nevertheless, the crucial role of the total capital ratio in explaining bank stability and performance profiles is corroborated also during the crisis period by the positive and statistically significant relationship with the distance to default and the positive and statistically significant relationship with ROA and PBR.

Regarding asset quality measures, we point out the negative and statistically significant relationship between the Texas ratio spread and systematic risk that differs from the positive relationship highlighted in the baseline results. This relationship suggests that banks which strongly deviate from the equilibrium level of coverage on troubled loans are associated with lower betas during the crisis period. This result is 
Table 5 Crisis

\begin{tabular}{|c|c|c|c|c|c|c|c|c|}
\hline & \multicolumn{5}{|l|}{ Risk } & \multicolumn{3}{|l|}{ Performance } \\
\hline & [1] & {$[2]$} & {$[3]$} & {$[4]$} & {$[5]$} & {$[6]$} & [7] & {$[8]$} \\
\hline TCR & $-0.043(0.081)$ & $\begin{array}{r}-0.016 \\
(0.041)\end{array}$ & $\begin{array}{r}-0.007 \\
(0.020)\end{array}$ & $0.091(0.102)$ & $\begin{array}{r}0.398 * * * \\
(0.057)\end{array}$ & $0.211 *(0.108)$ & $\begin{array}{r}0.856 * * * \\
(0.221)\end{array}$ & $\begin{array}{r}0.123 * * * \\
(0.030)\end{array}$ \\
\hline LEV & $\begin{array}{c}-0.845^{* *} \\
(0.399)\end{array}$ & $0.009(0.010)$ & $\begin{array}{c}-0.051^{* * * *} \\
(0.007)\end{array}$ & $\begin{array}{c}-1.655^{* * *} * \\
(0.578)\end{array}$ & $\begin{array}{c}-0.041 * * * \\
(0.012)\end{array}$ & $0.109(0.110)$ & $\begin{array}{c}-0.053 \\
(0.032)\end{array}$ & $0.022(0.015)$ \\
\hline TXR & $-0.010(0.050)$ & $\begin{array}{c}-0.128 * * * \\
(0.042)\end{array}$ & $0.021(0.024)$ & $\begin{array}{c}-0.219 * * * \\
(0.082)\end{array}$ & $\begin{array}{c}-0.222 * * * \\
(0.060)\end{array}$ & $0.102(0.062)$ & $\begin{array}{c}-0.268 \\
(0.178)\end{array}$ & $-0.033(0.024)$ \\
\hline LLPGL & $-0.011(0.026)$ & $0.004(0.020)$ & $\begin{array}{r}0.029 * * * \\
(0.009)\end{array}$ & $\begin{array}{c}-0.301 * * * \\
(0.042)\end{array}$ & $\begin{array}{c}-0.096^{* * *} \\
(0.027)\end{array}$ & $\begin{array}{r}0.240 * * * \\
(0.053)\end{array}$ & $\begin{array}{c}-0.297 * * * \\
(0.066)\end{array}$ & $\begin{array}{c}-0.047 * * * \\
(0.012)\end{array}$ \\
\hline $\mathrm{COV}$ & $-0.045(0.070)$ & $0.005(0.049)$ & $\begin{array}{r}0.032 * * * \\
(0.010)\end{array}$ & $0.026(0.070)$ & $\begin{array}{c}-0.082 * * * \\
(0.031)\end{array}$ & $0.026(0.058)$ & $\begin{array}{c}-0.134 * * \\
(0.051)\end{array}$ & $0.003(0.023)$ \\
\hline GRLSTD & $\begin{array}{r}-0.113^{*} \\
(0.065)\end{array}$ & $\begin{array}{r}-0.039 \\
(0.064)\end{array}$ & $\begin{array}{r}0.125 * * * \\
(0.030)\end{array}$ & $\begin{array}{c}-0.251^{* *} \\
(0.120)\end{array}$ & $\begin{array}{r}-0.086 \\
(0.064)\end{array}$ & $\begin{array}{r}-0.092 \\
(0.105)\end{array}$ & $\begin{array}{c}-0.380 * * * \\
(0.105)\end{array}$ & $0.005(0.050)$ \\
\hline SHORT & $-0.068(0.047)$ & $\begin{array}{r}0.074 * * \\
(0.032)\end{array}$ & $\begin{array}{r}0.120 * * * \\
(0.020)\end{array}$ & $\begin{array}{c}-0.307 * * * \\
(0.070)\end{array}$ & $\begin{array}{c}-0.265 * * * \\
(0.039)\end{array}$ & $0.023(0.061)$ & $\begin{array}{c}-0.558 * * * \\
(0.082)\end{array}$ & $-0.033(0.023)$ \\
\hline $\mathrm{EFF}$ & $-0.015(0.038)$ & $0.013(0.009)$ & $0.000(0.007)$ & $\begin{array}{c}-0.140 \\
(0.095)\end{array}$ & $0.007(0.011)$ & $\begin{array}{l}-0.070 \\
(0.056)\end{array}$ & $0.089(0.058)$ & $-0.009(0.009)$ \\
\hline LnTA & $\begin{array}{r}0.850 * * \\
(0.386)\end{array}$ & $\begin{array}{c}-0.725^{* *} \\
(0.330)\end{array}$ & $\begin{array}{c}-1.233 * * * \\
(0.163)\end{array}$ & $0.804(0.512)$ & $\begin{array}{r}0.679 * * \\
(0.327)\end{array}$ & $\begin{array}{r}1.310 * * \\
(0.587)\end{array}$ & $\begin{array}{r}2.832 * * * \\
(0.745)\end{array}$ & $\begin{array}{r}-0.388^{*} \\
(0.233)\end{array}$ \\
\hline GDP & $0.004(0.003)$ & $0.020(0.058)$ & $0.006(0.019)$ & $0.031(0.090)$ & $0.092 *(0.054)$ & $\begin{array}{c}-0.114 \\
(0.106)\end{array}$ & $\begin{array}{r}-0.116 \\
(0.093)\end{array}$ & $0.132(0.034)$ \\
\hline Cons & -0.114 & 0.157 & 0.256 & 0.172 & -0.295 & -0.176 & -0.181 & -0.263 \\
\hline Obs & 809 & 885 & 857 & 891 & 915 & 869 & 906 & 915 \\
\hline r-sq & $\begin{array}{l}0.7375 \\
\quad(0.3084)\end{array}$ & $\begin{array}{l}0.6742 \\
\quad(0.0034)\end{array}$ & $\begin{array}{l}0.9507 \\
(0.0000)\end{array}$ & $\begin{array}{l}0.5966 \\
\quad(0.0000)\end{array}$ & $\begin{array}{l}0.8005 \\
\quad(0.0000)\end{array}$ & $\begin{array}{l}0.5468 \\
(0.0000)\end{array}$ & $\begin{array}{l}0.6547 \\
(0.0000)\end{array}$ & $0.8655(0.0000)$ \\
\hline
\end{tabular}

This table reports the result for the fixed effects panel data regression analysis based on Eq. (9) performed over the crisis period (Q42008-Q42012). The dependent variables are: [1] Idiosyncratic risk; [2] Equity beta; [3]30d Stock Volatility; [4] Ln(Z-score); [5] Distance to default; [6] EVA; [7] ROA; [8]PBR. *, ** and *** indicate statistical significance at the $10 \%, \% 5$ and $1 \%$ levels, respectively. Robust standard errors are shown in brackets

unexpected, but it is plausible that the sign of this relationship is strongly influenced by the trends characterized by rapid increases in banks betas during the crisis period [53].

Model 3 corroborates the baseline results regarding the positive and statistically significant relationship between the LLP ratio and equity volatility confirming this relationship also over the crisis period but fails to confirm its positive and statistically significant relationship with equity betas. In addition, this result is further strengthened by the positive and statistically significant relationship between the coverage ratio and equity volatility.

Regarding the interlink between our asset quality variables and bank stability, the Texas ratio spread and the LLP ratio maintain their negative and statistically significant relationship with the Z-score and the distance to default corroborating their role as drivers of instability also during the crisis period.

Finally, the LLP ratio and the coverage ratio confirm their impact on performance variables as the former shows a positive and statistically significant relationship with EVA and a negative and statistically significant relationship with both
ROA and PBR, whereas the coverage ratio shows a negative and statistically significant relationship with ROA instead of EVA.

About the other variables, the positive and statistically significant relationship between our liquidity and funding variables with equity volatility holds also during the crisis period as well as the negative and statistically significant relationship between size and equity volatility. Regarding the interlink between our liquidity and funding variables with stability variables, only the ratio between short-term debt and total liabilities maintains its negative and statistically significant relationship with the distance to default and further gains statistical relevance in explaining the $\mathrm{Z}$-score therefore showing a stronger explanatory power of bank stability profiles during the crisis period.

With respect to performance variables, both the liquidity and funding variables confirm their negative and statistically significant relationship with ROA, to which size adds on showing a positive and statistically significant relationship, but all these variables fail to confirm their baseline 


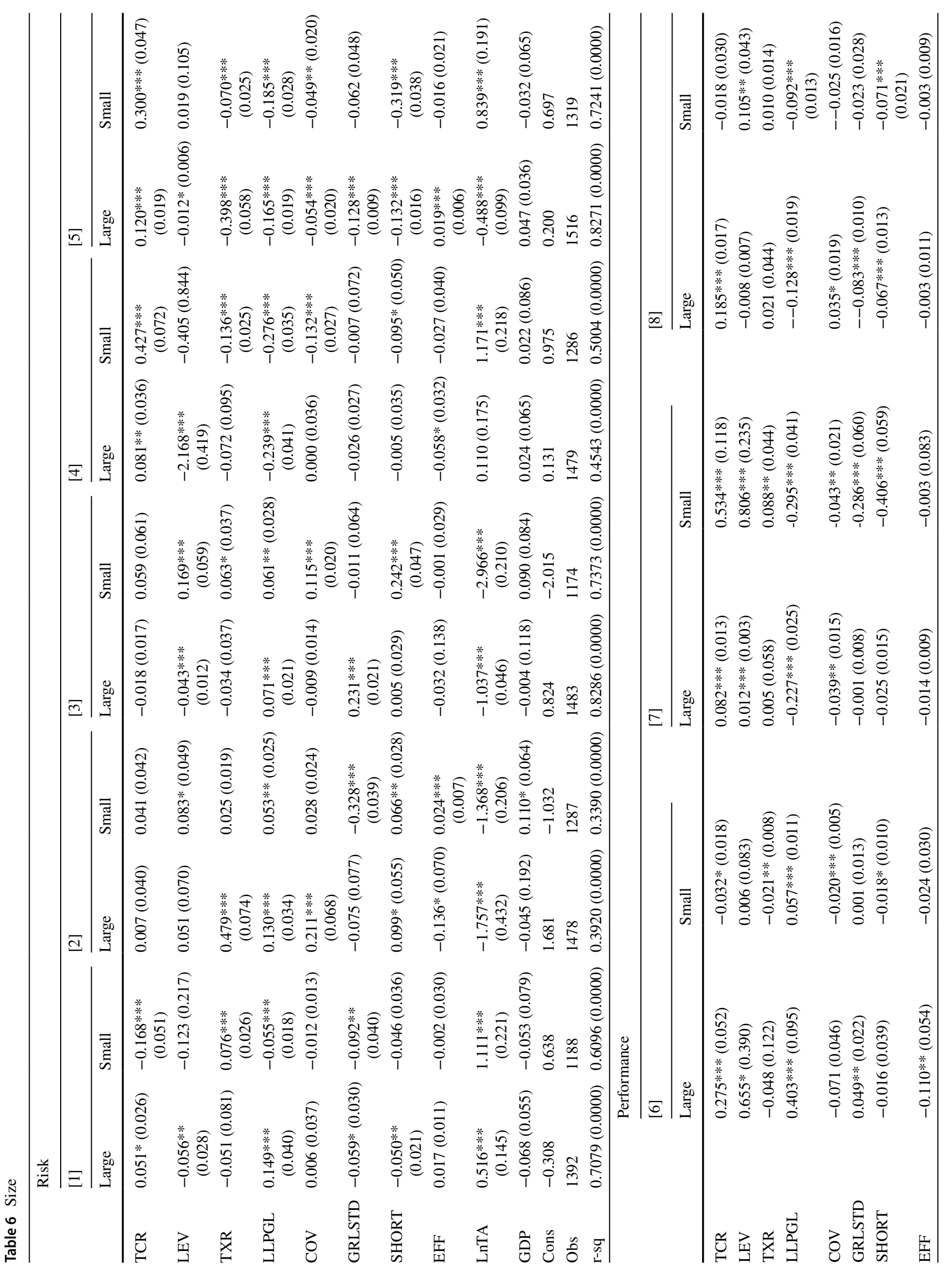

张 
relationships with PBR. Finally, as regards EVA, size does not maintain its positive and statistically significant relationship.

As second additional test, we check for eventual differences in the evolution of the relationships between asset quality and capital with bank risk and performance due to bank size. We, thus, rerun our baseline model for both large and small banks. Results are displayed in Table 6 .

Regarding our capital variables, the relationship between book leverage and equity volatility remains negative and statistically significant for large banks, whereas it turns positive and statistically significant for small banks. The former result corroborates the poor information content of the book leverage ratio, as outlined in previous analysis, which is simply perceived as a mere size measure. The latter, instead, supports the more traditional view of higher leverage associated with higher equity risk. Such difference may be due to the TBTF bias which makes an increase in leverage for large banks more tolerable than for small banks. About the relationship between the book leverage and our stability measures, the results only point out a negative and statistically significant relationship between the book leverage and the Z-score, coherently with the results obtained running the model over the crisis period but do not show any predictive power as regards small banks nor as regards the distance to default for both large and small banks. If the negative relationship with the Z-score seems to partly support the financial stability relevance of the leverage ratio as highlighted in the specification of the model regarding the crisis period, the lack of consistency with small banks and the absence of any predictive power when relating to the distance to default do not provide sufficient evidence to counter our suggestions stemming from the baseline model which indicate the book leverage ratio as poorly informative. Finally, we also find a positive and statistically significant relationship between the book leverage ratio and ROA of both large and small banks. This result is surprising as none of the previous analyses pointed out such relationship but is coherent with Calem and Robb [26] and Haq and Heaney (2012) who provide evidence of a positive association between book leverage and ROA.

Regarding the total capital ratio, the analysis points out a negative ad statistically significant relationship with idiosyncratic risk but only for small banks. This result differs from the results of the baseline model, but it is coherent with its negative and statistically significant relationship with equity volatility. The statistical relevance only for small banks may be symptomatic of a TBTF bias which relates the risk dynamics of large banks to drivers different from capital. As regards stability measures, the total capital ratio shows a positive and statistically significant relationship with the Z-score only for small banks. This result seems to corroborate our suggestions about a possible TBTF bias which

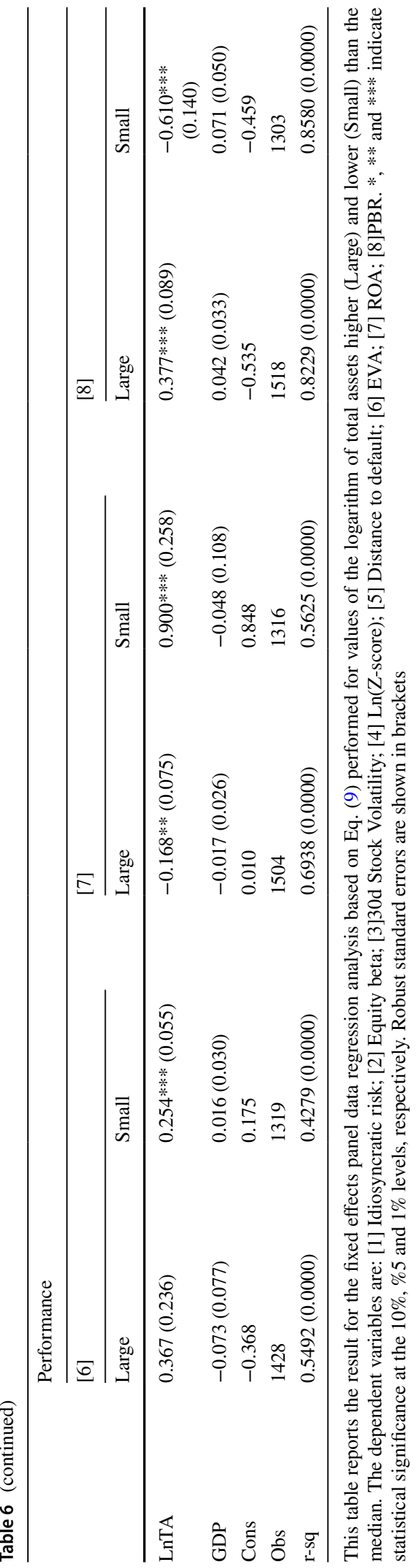


relates large banks' stability to different drivers. Regarding the distance to default, its relationship with the total capital ratio does not appear to be moderated by size as both large and small banks show a positive and statistically significant relationship in line with previous analyses' results. As regards performance variables, size does not appear to drive the relationship between ROA and the total capital ratio as both large and small banks show a positive and statistically significant relationship consistently with previous results. Instead, as regards both EVA and PBR, the total capital ratio shows a positive and statistically significant relationship only for large banks. Regarding EVA, a possible explanation is that while small banks increase it by raising the book leverage and increasing business risk, large banks may conversely pile up excess capital so to gain a competitive advantage and pursue more profitable businesses and costefficiency. Regarding the PBR, larger banks, which show the higher market-to-nook ratios, profits and dividends, do not face high costs when issuing equity thanks to their reputation so are usually associated with higher capital buffers which may drive the relationship outlined by our results. On the opposite, small banks may face more difficulties in raising equity therefore managing capital merely for regulatory purposes instead for catching growth opportunities which makes the total capital ratio a poor predictor of the PBR.

Regarding asset quality variables, the Texas ratio spread shows an unexpected positive and statistically significant relationship with idiosyncratic risk for small banks. The departure from the equilibrium level clearly affects idiosyncratic risk, and the statistical significance registered only for small banks is attributable to the higher capital buffers held by larger banks which may offset the alarm raised by a Texas ratio higher than the unit. The Texas ratio spread relationship with equity betas remains positive but gains statistical relevance only for large banks because of their higher interconnectedness with the financial system. With respect to stability measures, the Texas ratio spread presents a negative and statistically significant relationship with the distance to default for both large and small banks therefore supporting baseline results and rejecting size as a crucial moderator of this relationship. As regards the Z-score, instead, the Texas ratio spread shows a negative and statistically significant relationship only for small banks that may be due still to the excess capital harnessed by larger banks which mitigates the negative impact that deviations from the equilibrium have on stability. The LLP ratio points out contrasting results as regards its relationship with idiosyncratic risk as large banks show a positive and statistically significant relationship therefore supporting the stand of literature that claims the negative information value of provisioning, whereas small banks show a negative and statistically significant relationship that supports the literature view of provisioning as a mean to convey information to the market about future earnings rather than losses. This may be due to the inverse relationship that characterizes the relationship between bank size and propensity to signalling which would entice small banks to convey information about future earnings via provision, while large banks would merely manage provisions to abide by regulatory prescriptions [63].

As regards its relationship with equity betas, the LLP ratio shows a positive and statistically significant relationship for large banks which is coherent with baseline results and further supported by the same relationship between the coverage ratio and equity betas. The explanation still stems from the propensity of large banks to merely abide by provisioning rules.

The same relationship also emerges for the interlink between the LLP ratio and equity volatility, but, in this case, the coverage ratio gains statistical significance for small banks, instead.

As regards stability measures, size does not appear to moderate the relationship between the LLP ratio and both the Z-score and the distance to default as the relationship is negative and statistically significant for both large and small banks coherently with baseline results. The coverage ratio, instead, shows contrasting results about the role of size as moderator. It shows, indeed, a negative and statistically significant relationship with the Z-score for small banks and a negative and statistically significant relationship with the distance to default for large banks.

Regarding performance measures, size does not appear to moderate the relationship between the LLP ratio and EVA as both large and small banks show a positive and statistically significant relationship coherently with the baseline results and the signalling hypothesis linked with information regarding future earnings. Similarly, size is not a crucial driver of the relationship between the LLP ratio and both ROA and PBR as large and small banks display positive and statistically significant relationships with the LLP ratio in line with baseline results. Conversely, size seems to play an active role in moderating the relationship between the coverage ratio and both EVA and ROA. Indeed, the coverage ratio shows a negative and statistically significant relationship with EVA for small banks, whereas it shows a negative and statistically significant relationship with ROA for large banks. The sign of the relationships is coherent with previous analyses' results, but, in the case of EVA, it is in contrast with the fact that small banks are more likely to signal via provision their healthy financial status, whereas, in the case of ROA, it matches the view of large banks being more involved with abiding by provisioning rules therefore using providing to convey to the market information about future losses.

Regarding liquidity and funding variables, the ratio between gross loans to short-term funding and deposits shows a negative and statistically significant relationship 
with equity betas for small banks which previous analysis failed to detect. A possible explanation stems from the simpler structure of small banks, more focused on traditional business, whose work on core business may be rewarded in terms of lower systematic exposure. As regards equity volatility, our liquidity measure shows a positive and statistically significant relationship only for large banks, whereas our funding measure shows a positive and statistically significant relationship only for small banks. A possible explanation for the former result is that large banks may be more exposed to fluctuations of deposits and short-term funding than small banks which are instead more focused on traditional business. Accordingly, the latter result is explained by the expertise of small and simpler banks in managing short-term funding which may be perceived as positive by the market in terms of reduced equity volatility. With respect to stability measures, size does not appear to moderate the relationship between our funding measure and the distance to default as it is negative and statistically significant, coherently with baseline results, for both large and small banks. The liquidity measure, instead, shows a negative and statistically significant relationship with the distance to default only for large banks. This result is consistent with the negative and statistically significant relationship highlighted for large banks between our liquidity measure and equity volatility as short-term funding and deposits fluctuations may have a deeper impact on equity risk as well as insolvency risk. With respect to performance measures, our liquidity measure shows a negative and statistically significant relationship with ROA only for small banks. Low levels of liquidity and deposits for banks focused on traditional business may have a stronger impact on performance. The same relationship is highlighted for our funding measure. In this case, the strong reliance on short-term debt may cause small banks a severe backlash to profitability. Finally, as regards the PBR, size does not moderate the negative and statistically significant relationship with the funding measure which emerges for both large and small banks and is in line with baseline results. The liquidity measure, instead, shows a negative and statistically significant relationship with the PBR only for large banks in line with the above-mentioned discussed positive relationship with equity volatility and negative relationship with the distance to default.

Finally, we complement these analyses with a quantile regression which allows us to infer regarding the effect of capital and asset quality measures on the $25^{\text {th }}, 50^{\text {th }}$ and $75^{\text {th }}$ quantile of the distribution of the risk, stability and performance variables therefore providing a more detailed analysis of the relationships examined (Table 7).

Regarding Model 1, the book leverage enters significantly and negatively for banks with low levels of idiosyncratic risk indicating that lower levels of equity are associated with lower levels of idiosyncratic risk for banks with already low levels of idiosyncratic risk. This result may be due to the TBTF bias as less risky banks, protected by the government shield, may be able to increase leverage without experiencing repercussions in terms of higher idiosyncratic risk. Regarding asset quality variables, the Texas ratio spread enters significantly and positively for banks with low levels of idiosyncratic risk as well as the LLP ratio which extends and strengthens such relationship in magnitude also for banks with a moderate idiosyncratic risk. This result is coherent with the fact that higher departures from the equilibrium level of the Texas ratio as well as a negative signal about future losses provided by higher provisions may increase the idiosyncratic risk. Finally, the liquidity variable enters significantly and negatively for banks with moderate idiosyncratic risk and increases the magnitude of such relationship for banks with high levels of idiosyncratic risk. This result indicates that the higher the focus on the core business, the higher the resilience in terms of idiosyncratic risk in case of its escalation.

Regarding Model 2, the book leverage enters significantly and positively for banks with moderate values of the equity beta. The lower the level of the top-quality capital the higher the equity beta. The Texas ratio spread shows, instead, a significantly increasing effect on banks with moderate and high values of equity beta. This result indicates that the higher the departure from the equilibrium level of the Texas ratio the higher the market risk exposure for increasing levels of equity beta. A similar relationship is highlighted by the LLP ratio which shows a constant and increasing positive effect on equity betas from banks with low levels to high levels of equity beta. Our liquidity measure shows a constant and increasing negative effect on equity betas for higher quantiles of the equity beta's distribution. Finally, our funding measure enters significantly and positively for banks with moderate values of equity beta.

Regarding Model 3, the total capital ratio shows a significant and varying effect on equity volatility across all the quantiles of the distributions considered. The relationship is consistent with baseline results and suggests that there are no marked differences as regards the effect of the total capital ratio on equity volatility between the bottom and top percentiles of the distribution. The book leverage enters significantly and negatively for banks with low levels of equity beta. The relationship is coherent with baseline results and indicates that lower levels of equity are associated with lower levels of equity volatility for banks with already low levels of equity volatility. The Texas ratio spread enters significantly and positively for banks with low levels of equity volatility and extends this relationship to banks with a moderate level of equity volatility but with a less market magnitude. A similar effect is reported by the LLP ratio which, differently from the Texas ratio spreads, gains relevance also when explaining the highest quantile 


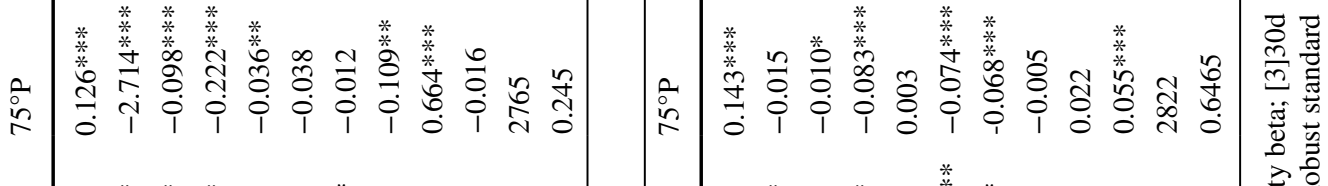

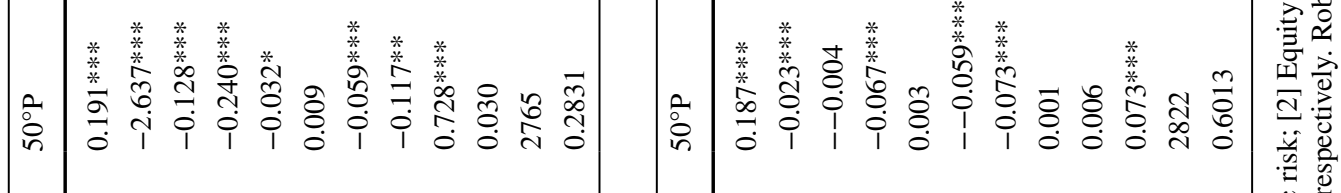

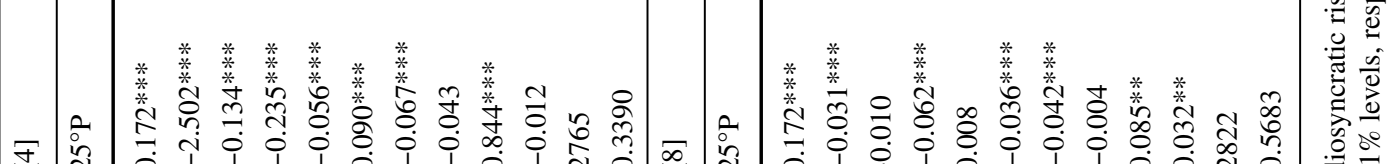

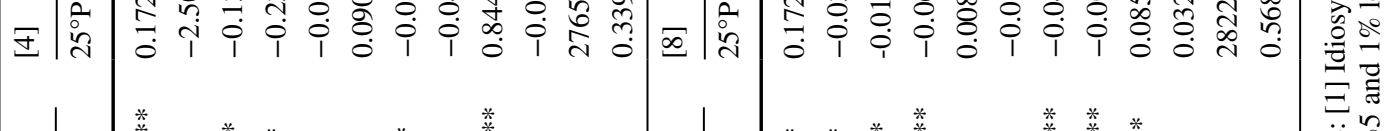

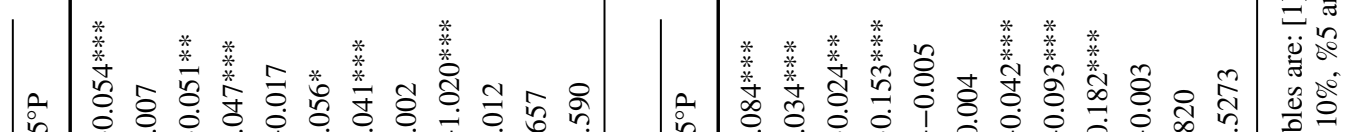
管

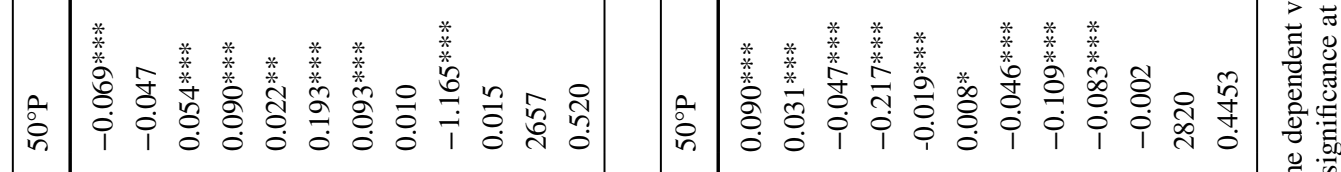

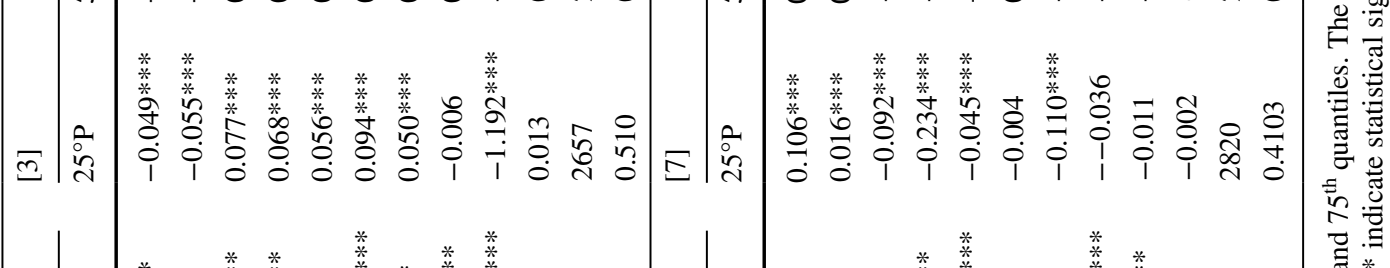

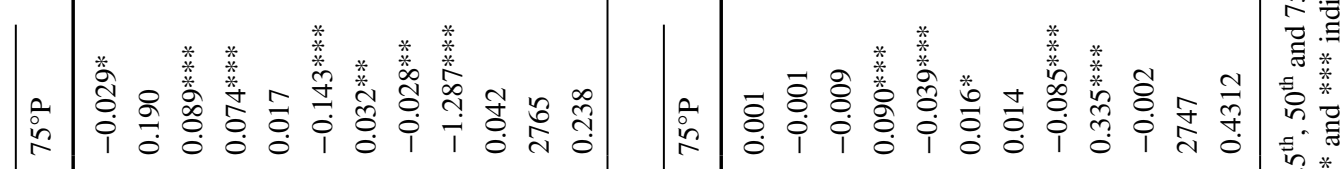

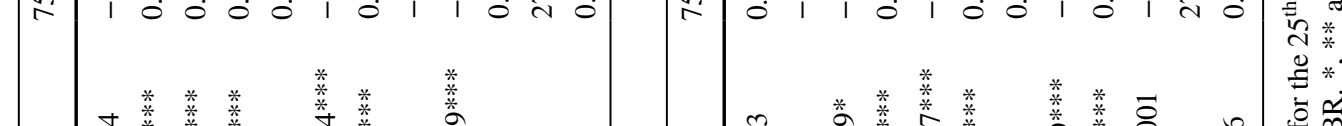

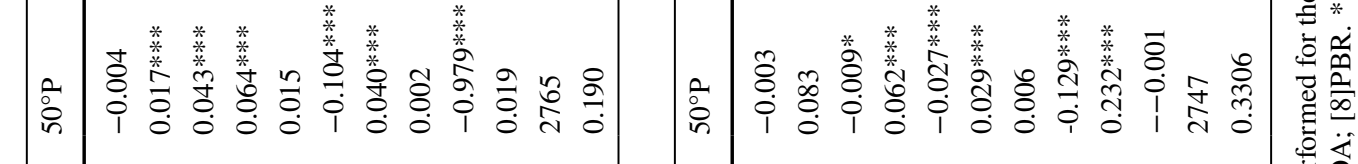
ऽ

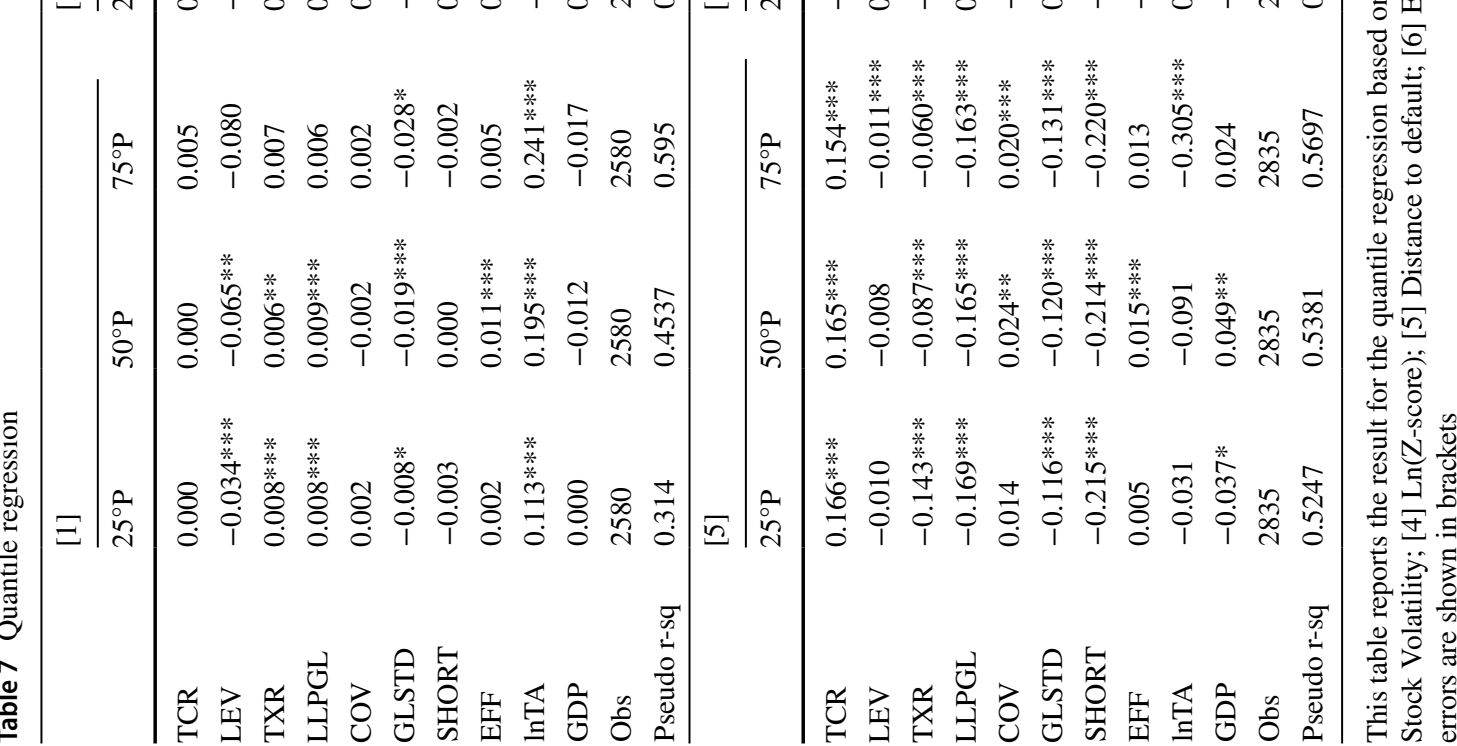


of the distribution of equity volatility. Also the coverage ratio enters significantly and positively for banks with low levels of equity volatility but its effect declines for the upper quantiles. Our liquidity measure enters significantly and positively for banks with low levels of equity volatility and increases the effect also for banks with moderate levels of equity volatility. The result is coherent with the relationship highlighted in the baseline model. Finally, the funding measure shows a significant and varying effect on equity volatility across all the quantiles of the distributions considered. The relationship is consistent with baseline results and suggests that there are no marked differences as regards the effect of the total capital ratio on equity volatility between the bottom and top percentiles of the distribution.

Regrading Model 4, all the capital and some of the asset quality measures show a significant effect on the Z-score coherent with the relationships highlighted by baseline results across all the quantiles of the distribution of the $\mathrm{Z}$-score. In particular, the total capital ratio shows a positive and varying effect, the book leverage shows a negative and increasing effect, the Texas ratio spread shows a negative and decreasing effect, and the LLP ratio shows a negative and varying effect. These results do not suggest marked differences between the bottom and top percentiles of the distribution as regards these variables. The coverage ratio, instead, enters significantly and negatively for banks with lower values of $\mathrm{Z}$-score indicating its crucial role as instability driver for banks approaching bankruptcy. Our liquidity measure enters significantly and positively for unstable banks as lack of liquidity is a fundamental driver of failure for banks approaching such conditions. Finally, the funding measure enters significantly and negatively for unstable banks maintaining this effect also for banks characterized by moderate values of $\mathrm{Z}$-score. This result is coherent with the relationship highlighted in the baseline model as stronger reliance on short-term funding increases the exposure to liquidity shocks and drives to instability.

Regarding Model 5, the total capital ratio enters significantly and positively for banks close to bankruptcy and the effect persists across all quantiles of the distance to default distribution but with decreasing magnitude. This result suggests that capital plays a fundamental role in explaining bank stability especially when the bank is approaching bankruptcy. The book leverage, instead, enters significantly and negatively for less risky banks. We, therefore, infer its poor prediction ability of bank stability with respect to the total capital ratio, also coherently with Model 4 results and the baseline model. The Texas ratio enters significantly and negatively for banks with lower values of distance to default, showing a decreasing effect for higher percentiles. This result is coherent with Model 4 and the relationship highlighted by the baseline model. Similarly, the LLP ratio enters significantly and negatively for banks in the lowest percentile considered of the distribution and its effect decreases for higher percentiles. The coverage ratio, instead, enters significantly and positively for banks positioned in the highest percentile of the distance-to-default distribution. This result suggests a poor role for the coverage ratio as failure predictor. The liquidity measure enters significantly and negatively for banks with lower values of the distance to default and its effect maintains across all the percentiles of the distribution but slightly increasing. The relationship is coherent with baseline results. The same effect and magnitude trend is presented by the funding measure in line with baseline results.

Regarding Model 6, capital measures do not show any significant effect. About asset quality measures, the Texas ratio spread enters significantly and negatively for banks positioned in the lowest percentile of the EVA's distribution, whereas the LLP shows a thorough and increasingly positive effect across all quantiles considered. However, this result is in contrast with the significant and increasingly negative effect of the coverage ratio across all quantiles considered of the EVA's distribution but in line with baseline relationships and explanations. Finally, the liquidity measure enters significantly and positively for banks positioned in the 50th percentile of EVA's distribution.

Regarding Model 7, both the total capital ratio and the leverage enter significantly and positively for low profitable banks and the effect persists across all quantiles considered, but whether the former's effect decreases the latter's effect increases. The relationships are in line with baseline results. Regarding asset quality measures, both the Texas ratio spread and the coverage ratio enter significantly and negatively for less profitable banks and the effect persists, with minor magnitude, only up to moderate profitable banks then disappears. The LLP ratio, instead, shoes the same effect and magnitude trend but persists also for the upper quartile of the ROA's distribution. The relationships are in line with baseline results and considerations. Finally, the funding structure enters significantly and negatively for less profitable banks and its effect persists but decreases for the higher percentiles considered. The relationship is in line with baseline results.

Regarding Model 8, the total capital ratio shows a significant and positive varying effect on PBR across all quantiles considered, whereas the book leverage shows a significant and negative decreasing effect on PBR for the bottom and middle quartile of its distribution. The former relationship is in line with baseline results, whereas the latter suggests that leverage is not a good predictor for high banks' PBRs. Regarding asset quality measures, the LLP ratio enters significantly and negatively for low-PBR banks, and this effect increases for the higher percentiles. The relationship is in line with baseline results. Finally, our liquidity measure shows a significant and negative increasing effect on PBV 
across all quantiles considered, whereas the funding measure shows a significant and negative varying effect on PBV across all quantiles considered. The related relationships are in line with baseline results.

\section{Conclusions and implications}

Using a sample of 63 European banks and quarterly data over the period 2005-2018, this paper investigates the relationship between capital and asset quality with bank risk and performance. Our main contribution to the literature consists in disentangling the complex concepts of capital and asset quality as well as bank risk and performance by employing several definitions of each of these banking dimensions, thereby providing both a more detailed and comprehensive picture of the connections between them and an interpretative framework which accounts for the recent NPL's regulation overhaul.

Regarding the capital measures employed in this study, our findings point out a significant and negative relationship between the simple book leverage ratio and equity volatility which is consistent during the crisis period and for large banks. In addition, the effect of the leverage ratio on equity volatility is significant only in relation with the 25 th quantile of the latter's distribution. Our interpretation of the result is that the information content of the book leverage is negligible and mostly referred to a dimensional feature [58].

Our risk-based capital measure, the total capital ratio is instead a poor predictor of idiosyncratic risk, systematic risk and equity volatility. Nevertheless, it shows a positive and statistically significant relationship with both the Z-score and the distance to default. As such, risk-based capital ratios are effective in enhancing bank stability and reducing its distance to default. These findings hold during the crisis period with respect to insolvency risk whose relationship with the total capital ratio does not appear to be moderated by size contrary to the relationship between the total capital ratio and the Z-score which appear to be significant only for small banks which we attribute to the TBTF bias. In addition, the quantile regression analysis does not point out marked differences regarding the effect of the total capital ratio on the risk and stability variables above-mentioned between the lowest and highest percentiles of their distribution. With respect to performance variables, instead, the total capital ratio shows a positive and statistically significant relationship with all the measures employed which is further confirmed for the crisis period, as regards ROA and PBR. Size does not moderate the relationship between the total capital ratio and ROA but moderates that with EVA and PBV for large banks which we attribute to their excess capital management dynamics. In addition, the quantile regression analysis does not bring out marked differences as regards the effect of the total capital ratio on ROA and PBR between the lowest and highest percentiles of their distribution.

As regards asset quality variables, the Texas ratio spread shows a consistent and negative relationship with both stability measures which holds during the crisis period. Bank size does not appear to moderate the relationship between the Texas ratio spread and the distance to default but moderates that with the Z-score for small banks which we attribute to the excess capital harnessed by large banks which may offset the negative impact due to deviating from the equilibrium. In addition, the quantile regression analysis does not report marked differences between as regards the effect of the Texas ratio on both stability measures between the lowest and highest percentiles of their distribution.

Consistently, the LLP ratio shows the same relationship and effects on both stability measures. However, differently from the Texas ratio spread, size does not play a moderating role in its relationship with the Z-score. Coherently, the LLP ratio shows a significant and positive relationship with the equity beta and equity volatility in the baseline model which holds during the crisis period for equity volatility. As regards bank size, it appears to moderate all the relationships between the LLP ratio and the risk variables suggesting a propensity for large banks to merely abide by provisioning rules in contrast with small banks' propensity to harness provisioning as a mechanism for signalling about future earnings. The LLP ratio also shows a negative and consistent relationship with ROA and PBR which is consistent during the crisis period and not moderated by bank size and further does not show marked differences in terms of effect of the LLP ratio on performance variables with respect to their distribution. The LLP ratio and EVA, instead, shows a positive relationship, consistent across the crisis period, not moderated by size and with a significant effect across all the EVA's distribution which, however, is confuted by the results on the negative and significant relationship between the coverage ratio and EVA. The result is that we cannot draw robust conclusions about the signalling effect suggested by the relationship between the LLP ratio and EVA nor about the negative signal suggested by the relationship between the coverage ratio and EVA. Finally, the coverage ratio does not show a consistent relationship with the variables considered in this study but the scattered relationships highlighted mainly support the conclusions drawn by the LLP ratio as regards provisioning policies.

As regards the liquidity and funding measures, both show a consistent and positive relationship with equity volatility across all analyses employed therefore suggesting that a lack of liquidity and a strong reliance on short-term funding both increase risk. Coherently, both measures also show a significant and negative relationship with the distance to default, as regards stability measures, and ROA and PBR, as regards performance measures for baseline results. These 
relationships mainly hold also for the crisis period as both liquidity and funding measures are negatively related to ROA and the funding measure still shows a negative relationship with the distance to default and the Z-score as well. As regards the moderating effect of size, the relationships between the distance to default and the funding measure and between the PBR and the funding measure are not moderated by size, whereas for the same dependent variables, size moderates the negative relationship with the liquidity measure for large banks because of their higher sensitivity to fluctuations of deposits and short-term funding. Both the liquidity and funding measures are, instead, significantly moderated by size when related to the ROA for small banks due to the intrinsic characteristics of their business models. The effect of the liquidity and funding measures on the dependent variables abovementioned mainly does not show marked differences with respect to their distributions.

According to our results, the negative implications that severe provisioning policies may have on bank stability and performance should warn policymakers about reconsidering the measures deployed to overhaul the NPLs' regulation, especially in the light of the outbreak of the pandemic which is likely to jeopardize the efforts made so far to counter the NPL issue in Europe. In detail, the supervisory expectations regarding the level of coverage on non-performing exposures may cause unprofitable rushed disposals which would affect the capital base. In addition, such approach would also have negative repercussions on profits and the bank's capital generation ability as emerges from our in-depth analysis of the Texas ratio. In short, forcing banks to pursue more severe hefty provisioning policies could undermine bank stability and performance, especially in a context already characterized by a weak level of profitability [45]. Moreover, the results highlighted by our capital measures cast some shadows on the purpose of the minimum coverage level of making the risks associated to NPLs better reflected in the CET 1 capital ratios. In detail, our results about the leverage ratio point out that it is a poor predictor of bank risk and suggests that it may be perceived only as measure of size by investors. Conversely, the total capital ratio appears to be a crucial driver of bank stability. However, risk-weighted capital ratios are exposed to manipulation by management that struggles to comply with capital regulation [27]. We, therefore, raise some concerns regarding their ability to accurately reflect the real risk exposition of banks. This ultimately undermines regulatory purposes of increasing CET1 sensitivity to the risks associated to NPLs.

Finally, we provide additional evidence of the positive relationship between capital and bank performance and further suggest it as leading driver of regulatory purposes of higher coverages and more stability.

\section{Appendix 1}

Here we disentangle the main economic drivers underlying the Texas ratio. We start from the basic formulation of the Texas ratio that relates the gross value of NPLs with the sum of the loan loss reserves, related to performing and non-performing exposures, and the tangible common equity. We first divide both the numerator and the denominator by total gross loans $(\mathrm{TL}=\mathrm{NPL}+\mathrm{PL})$ obtaining the following formulation:

Texas Ratio $=\frac{\frac{\mathrm{NPL}}{\mathrm{TL}}}{\frac{\mathrm{LLR}_{\mathrm{NP}+\mathrm{PL}}}{\mathrm{TL}}+\frac{\mathrm{TCE}}{\mathrm{TL}}}$

The variable $\frac{\mathrm{LLR}_{\mathrm{NP}+\mathrm{PL}}}{\mathrm{TL}}$ represents the total coverage which can be broken down into the weighted average of coverage rates related to performing and non-performing loans as follows:

$\frac{\mathrm{LLR}_{\mathrm{NP}+\mathrm{PL}}}{\mathrm{TL}}=\frac{\mathrm{LLR}_{\mathrm{PL}}}{\mathrm{PL}} \cdot \frac{\mathrm{PL}}{\mathrm{TL}}+\frac{\mathrm{LLR}_{\mathrm{NP}}}{\mathrm{NPL}} \cdot \frac{\mathrm{NPL}}{\mathrm{TL}}$

Thus, given that $\frac{\mathrm{LLR}_{\mathrm{NP}}}{\mathrm{NPL}}$ is comparable to the loss given default and that the expected average loss can be expressed as $\frac{\mathrm{LLR}_{\mathrm{NP}+\mathrm{PL}}}{\mathrm{TL}}=\mathrm{PD} \cdot \frac{\mathrm{LLR}}{\mathrm{NPL}}$, then Eq. 2 can be rewritten as follows:

$\frac{\mathrm{LLR}_{\mathrm{PL}+\mathrm{NP}}}{\mathrm{TL}}=\frac{\mathrm{LLR}_{\mathrm{NP}}}{\mathrm{NPL}} \cdot\left[\left(\mathrm{PD}_{\mathrm{PL}} \cdot \frac{\mathrm{PL}}{\mathrm{TL}}\right)+\frac{\mathrm{NPL}}{\mathrm{TL}}\right]$

As a result, Eq. 3 is able to express the total coverage ratio as the product of the implicit loss given default with the weighted average of performing loans and NPLs, respectively. Thus, the total coverage ratio results function of: (i) the coverage ratio of NPLs, $c r=\left(\frac{L_{L} R_{N P}}{N P L}\right)$; (ii) the implicit probability for performing loans to turn non-performing, $\mathrm{PD}_{\mathrm{PL}}$; and the ratio between non-performing loans and total loans, $\frac{\mathrm{NPL}}{\mathrm{TL}}$.

The tangible common equity can be expressed by the following equation:

$\mathrm{TCE}=\mathrm{RAC}+\mathrm{ETC}$

where: RAC is the regulatory capital absorbed and ETC is the excess tangible capital. The latter represents the tangible capital not absorbed by the credit risk on NPLs and available to bear the other risk as per the Basel regulatory framework. According to the latter, the regulatory capital absorbed can be written as follows:

$\mathrm{RAC}=k \cdot w \cdot\left(\mathrm{NPL}-\mathrm{LLR}_{\mathrm{NP}}\right)(5)$

where: $k$ is the capital absorption coefficient and $w$ is the weighting coefficient for NPLs. As a result, the tangible common equity can be rewritten as follows: 
$\frac{\mathrm{TCE}}{\mathrm{TL}}=\frac{\mathrm{TCE}}{\mathrm{NPL}} \cdot \frac{\mathrm{NPL}}{\mathrm{TL}}=\left(\frac{\mathrm{RAC}}{\mathrm{NPL}} \cdot \frac{\mathrm{NPL}}{\mathrm{TL}}\right)+\left(\frac{\mathrm{ETC}}{\mathrm{NPL}} \cdot \frac{\mathrm{NPL}}{\mathrm{TL}}\right)$

We, thus, indicate $\frac{\text { RAC }}{\text { NPL }}$ with $\beta$; $\frac{\text { ETC }}{\text { NPL }}$ with $\alpha$; and $\frac{\text { NPL }}{\text { TL }}$ with $\eta$, to obtain the following equation:

$\frac{\mathrm{TCE}}{\mathrm{TL}}=\eta \cdot(\beta+\alpha)$

As $\beta=w \cdot k \cdot(1-$ cr $)$, Eq. 7 can be rewritten as follows:

$\frac{\mathrm{TCE}}{\mathrm{TL}}=\eta \cdot[w \cdot k \cdot(1-\mathrm{cr})+\alpha]$

The Texas ratio can be, therefore, expressed by the following equation:

Texas Ratio $=\frac{\eta}{\eta \cdot[w \cdot k \cdot(1-\mathrm{cr})+\alpha]+\mathrm{cr} \cdot\left[\mathrm{PD}_{\mathrm{PL}} \cdot(1-\eta)+\eta\right]}$

From which:

Texas Ratio $=\frac{1}{w \cdot k \cdot(1-\mathrm{cr})+\mathrm{cr} \cdot\left(1+\mathrm{PD}_{\mathrm{PL}} \cdot \frac{\mathrm{PL}}{\mathrm{NPL}}\right)+\alpha}$

Finally, in the case of absence of loan loss reserves for performing loans (i.e. $\mathrm{PD}_{\mathrm{PL}}=0$ ), then:

Texas Ratio $=\frac{1}{w \cdot k \cdot(1-\mathrm{cr})+\mathrm{cr}+\alpha}$

\section{Declarations}

Conflict of interest On behalf of all authors, the corresponding author states that there is no conflict of interest.

\section{References}

1. Agusman, A., G.S. Monroe, D. Gasbarro, and J.K. Zumwalt. 2008. Accounting and capital market measure of risk: Evidence from Asian banks during 1998-2003. Journal of Banking and Finance 32 (4): 480-488.

2. Akovali, U., Yilmaz, K. 2016. Idiosyncratic vs Systematic Risk: A Network Risk Model via Portfolio Risk Decomposition. https:// editorialexpress.com/cgi-bin/conference/download.cgi?db_ name $=$ SNDE2017\&paper_id $=193$

3. Altunbas, Y., S. Carbo, E.P.M. Gardner, and P. Molyneux. 2007. Examining the Relationships between Capital, Risk and Efficiency in European Banking. European Financial Management 13 (1): 49-70.

4. Anandarajan, A., I. Hasan, and C. McCarthy. 2007. Use of loan loss provisions for capital, earnings management and signaling by Australian banks. Accounting and Finance 47 (3): 357-379.

5. Anginer, D., A. Demirguc-Kunt, H. Huizinga, and K. Ma. 2018. Corporate Governance of Banks and Financial Stability. Journal of Financial Economics 130 (2): 327-346.
6. Anginer, D., Demirgüç-Kunt, A. 2014. Bank capital and systemic stability. https://openknowledge.worldbank.org/bitstream/handle/ 10986/19377/WPS6948.pdf?sequence=1\&isAllowed=y

7. Athanasoglou, P., S. Brissimis, and D. Matthaios. 2008. Bankspecific, industry-specific and macroeconomic determinants of bank profitability. Journal of International Financial Markets, Institutions and Money 18 (2): 121-136.

8. Aubuchon C., Wheelock D. 2010. The Geographic Distribution and Characteristics of U.S. Bank Failures, 2007-2010: Do Bank Failures Still Reflect Local Economic Conditions?. Federal Reserve Bank of St. Louis Review, 92(5); 395-415.

9. Avignone, G., Altunbas, Y., Polizzi, S., Reghezza, A. 2021 Journal of International Money and Finance, 110: 102264.

10. Baker, M., Wurgler, J. 2013 Do strict capital requirements raise the cost of capital? Banking regulation and the low risk anomaly. https://pubs.aeaweb.org/doi/pdfplus/https://doi.org/10.1257/aer. p20151092

11. banking systems", Procedia Economics and Finance, Vol. 20, pp. 518-524.

12. Beaver, W.H., C. Eger, S.G. Ryan, and M. Wolfson. 1989. Financial reporting, supplemental disclosures, and bank share price. Journal of Accounting Research 27: 157-178.

13. Beck, T., O. De Jonghe, and G. Schepens. 2013. Bank competition and stability: Cross-country heterogeneity. Journal of Financial Intermediation 22 (2): 218-244.

14. Beltrame, F., D. Previtali, and A. Sclip. 2018. Systematic risk and banks leverage: The role of asset quality. Finance Research Letters 27: 113-117.

15. Beltratti, A., and R.M. Stulz. 2012. The credit crisis around the globe: Why did some banks perform better. Journal of Financial Economics 105 (1): 1-17.

16. Berger, Allen N., and H.S. Bouwman Christa. 2013. How does capital affect bank performance during financial crisis. Journal of Financial Economics 109: 146-176.

17. Bernanke, B. 2008. Liquidity Provision by the Federal Reserve. https://www.federalreserve.gov/newsevents/speech/bernanke20 080513.htm

18. Besanko, D., and G. Kanastas. 1996. The Regulation of Bank Capital: Do Capital Standards Promote Bank Safety? Journal of Financial Intermediation 5 (2): 160-183.

19. Bhat, V.N. 1996. Banks and income smoothing: An empirical analysis. Applied Financial Economics 6 (6): 505-510.

20. Bitar, M., K. Pukthuanthong, and T. Walker. 2018. The effect of capital ratio on the risk, efficiency and profitability of banks: Evidence from OECD countries. Journal of International Financial Markets, Institutions and Money 53: 227-272.

21. Blum, J. 1999. Do capital adequacy requirements reduce risks in banking? Journal of Banking and Finance 23 (5): 755-771.

22. Bogdanova, B., Fender, I., Takáts, E. 2018. The ABCs of bank PBRs: What drives bank price-to-book ratios? https://www.bis. org/publ/qtrpdf/r_qt1803h.htm

23. Borio, C., L. Gambacorta, and B. Hofmann. 2017. The influence of monetary policy on bank profitability. International Finance 20: 48-63.

24. Brunnermeier, M. 2009. Deciphering the Liquidity and Credit Crunch 2007-2008. Journal of Economic Perspectives 23: 77-100.

25. Bushman, R.M., and C.D. Williams. 2015. Delayed Expected Loss Recognition and the Risk Profile of Bank. Journal of Accounting Research 53 (3): 511-553.

26. Calem, P., and R. Rob. 1999. The Impact of Capital-Based Regulation on Bank Risk-Taking. Journal of Financial Intermediation 8 (4): 317-352.

27. Cathcart, L., L. El-Jahel, and R. Jabbour. 2015. Can regulators allow banks to set their own capital ratios? Journal of Banking and Finance 53 (4): 112-123. 
28. Chiaramonte, L., E. Croci, and F. Poli. 2015. Should we trust the Z-score? Evidence from the European Banking Industry. Global Finance Journal 28: 111-131.

29. Chiaramonte, L., and B. Casu. 2016. Capital and Liquidity Ratios and Financial Distress. Evidence from the European Banking Industry, The British Accounting Review 49 (2): 138-161.

30. Cihak, M., Hesse, H. 2010. Islamic Banks and Financial Stability: An Empirical Analysis. https://www.imf.org/external/pubs/ft/wp/ 2008/wp0816.pdf

31. Coffinet, J., V. Coudert, A. Pop, and C. Pouvelle. 2012. Two-way interplays between capital buffers and credit growth: Evidence from French banks. Journal of International Financial Markets, Institutions and Money 22 (5): 1110-1125.

32. Cole, R., and L. White. 2012. Dèja Vu All Over Again: The Causes of U.S. Commercial Bank Failures This Time Around. Journal of Financial Services Research 42: 5-29.

33. Constancio, V. 2017. Resolving Europe's NPL Burden: Challenges and Benefits. https://www.ecb.europa.eu/press/key/date/ 2017/html/sp170203.en.html

34. Delis, D.M., and G.P. Kuoretas. 2011. Interest rates and bank risk-taking. Journal of Banking and Finance 35 (4): 840-855.

35. Dell'Ariccia, G., and L. Ratnovski. 2013. Bailouts and Systemic Insurance. Journal of Banking and Finance 105: 166-177.

36. Demirguc-Kunt, A. 1998. The determinants of Banking Crises in Developing and Developed Countries. IMF Staff Papers 45 (1): 81-107.

37. Demirguc-Kunt, A., Detragiache, E., Merrouche, O. 2013. Bank Capital: Lessons from the Financial Crisis. https://www.elibr ary.imf.org/view/journals/001/2010/286/article-A001-en.xml.

38. Demirgüç-Kunt, A., and H. Huizinga. 2010. Bank activity and funding strategies: The impact on risk and returns. Journal of Financial Economics 98 (3): 626-650.

39. Dewatripont, M., and J. Tirole. 1994. 1994. New York: The prudential regulation of banks. MIT Press.

40. DeYoung, R., and G. Torna. 2013. Non-traditional banking activities and bank failures during the financial crisis. Journal of Financial Intermediation 22: 397-421.

41. Di Biase, P., and E. D'Apolito. 2012. The determinants of Systematic Risk in the Italian Banking System_ A Cross-Sectional Time Series Analysis. International Journal of Economics and Finance 4 (11): 152-164.

42. Diamond, D.W., and P.H. Dybvig. 1983. Bank runs, Deposit Insurance, and Liquidity. The Journal of Political Economy 91 (3): 401-419.

43. Ding, D., and R.C. Sickles. 2018. Frontier efficiency, capital structure, and portfolio risk: An empirical analysis of US banks. BRQ Business Research Quarterly 21 (4): 262-277.

44. Du, B., and D. Palia. 2018. Short-Term Debt and Bank Risk. Journal of Financial and Quantitative Analysis. 53 (2): 815-835.

45. EBA. 2018. Risk Dashboard Data as of Q4 2018. London: European Banking Authority.

46. ECB. 2017. Guidance to Banks on Non-Performing Loans, European Central Bank, Frankfurt.

47. ECB. 2018. Addendum to the ECB Guidance to Banks on Nonperforming Loans: Supervisory Expectations for Prudential Provisioning of Non-Performing Exposures, European Central Bank, Frankfurt.

48. ECB. 2020. Supervisory Banking Statistics: Third Quarter 2019, European Central Bank, Frankfurt.

49. Espinoza, R., Prasad, A. 2010. Nonperforming Loans in the GCC Banking System and their Macroeconomic Effects. https://www. imf.org/external/pubs/ft/wp/2010/wp10224.pdf

50. Ferrarin, A., Polato, M., and Velliscig, G. (2020). Disentangling the Texas ratio: the case of the Italian banking sector.
International Journal of Managerial and Financial Accounting, 12(3/4): 217-241. https://doi.org/10.1504/IJMFA.2020.112335

51. Fiordelisi, F. 2007. Shareholder value efficiency in European banking. Journal of Banking and Finance 31 (7): 2151-2171.

52. Fiordelisi, F., and P. Molyneux. 2010. The determinants of shareholder value in European Banking. Journal of Banking and Finance 34: 1189-1200.

53. Floreani J., Polato M., Paltrinieri A., Pichler F. 2015. Credit quality, bank provisioning and systematic risk in banking business. In: Beccalli E., Poli F. (eds) Bank Risk, Governance and Regulation. Palgrave Macmillan Studies in Banking and Financial Institutions. Palgrave Macmillan, London.

54. Fraker, G. T. 2006. Using Economic Value Added (EVA) to Measure and Improve Bank Performance. Paper Writing Contest, RMA - Arizona Chapter.

55. Goddard, J., Molyneux, P., Wilson, J. 2004. The Profitability of European Banks: A Cross-Sectional and Dynamic Panel Analysis. https://citeseerx.ist.psu.edu/viewdoc/download?doi=10.1.1.378. $4433 \&$ rep $=$ rep $1 \&$ type $=$ pdf

56. Gonzalez-Hermosillo, B. 1999. Determinants of Ex-Ante Banking System Distress: A Macro-Micro Empirical Exploration of Some Recent Episodes. https://www.imf.org/en/Publications/WP/Issues/ 2016/12/30/Determinants-of-Ex-Ante-Banking-System-DistressA-Macro-Micro-Empirical-Exploration-of-Some-2908

57. Haq, M., and R. Heaney. 2012. Factors determining European bank risk. Journal of International Financial Markets, Institutions and Money 22 (4): 696-718.

58. Hasan, I., A. Siddique, and X. Sun. 2015. Monitoring the "invisible" hand of market discipline: Capital adequacy revisited. Journal of Banking and Finance 50: 475-492.

59. Imbierowicz, B., and C. Rauch. 2014. The relationship between liquidity risk and credit risk in banks. Journal of Banking and Finance 40 (4): 242-256.

60. Jesswein, K.R. 2009. Bank failure models: A preliminary examination of the "Texas" ratio. Proceedings of the Academy of Banking Studies 9 (1): 2-6.

61. Jimenez, G., A.J. Lopez, and J. Saurina. 2008. How does Competition Impact Bank Risk-Taking? Journal of Financial Stability 9 (2): 185-195.

62. Jokipii, T., and A. Milne. 2008. The cyclical behaviour of European bank capital buffers. Journal of Banking and Finance 32 (8): $1440-1451$.

63. Kabir, Md.N., A. Worthington, and R. Gupta. 2015. Comparative credit risk in Islamic and conventional bank. Pacific-Basin Finance Journal 34: 327-353.

64. Kanagaretnama, K., G.J. Lobo, and D.-H. Yang. 2005. Determinants of signaling by banks through loan loss provisions. Journal of Business Research 58 (3): 312-320.

65. Kim, M., and W. Kross. 1998. The impact of the 1989 change in bank capital standards on loan loss provisions and loan write-offs. Journal of Accounting and Economics 25 (1): 69-99.

66. Klein, N. 2013. Non-Performing Loans in CESEE: Determinants and Impact on Macroeconomic Performance. https://www.imf. org/en/Publications/WP/Issues/2016/12/31/Non-PerformingLoans-in-CESEE-Determinants-and-Impact-on-Macroecono mic-Performance-40413

67. Laeven, L., and R. Levine. 2009. Bank governance, regulation and risk taking. Journal of Financial Economics 93 (2): 259-275.

68. Laeven, L., L. Ratnovski, and H. Tong. 2016. Bank size, capital, and systemic risk: Some international evidence. Journal of Banking and Finance 69: S25-S34.

69. Lee, C.-C., and M.-F. Hsieh. 2013. The Impact of Bank Capital on Profitability and Risk in Asian Banking. Journal of International Money and Finance 32: 251-281. 
70. Liu, H., P. Molyneux, and J. Wilson. 2012. Competition and stability in European banking: A regional analysis. The Manchester School 81: 176-201.

71. Mahdi, I.B.S., and M.B. Abbes. 2018. Relationship between capital, risk and liquidity: A comparative study between Islamic and conventional banks in MENA region. Research in International Business and Finance 45: 588-596.

72. Marshall, A. 1890. Principles of Economics. London: The Macmillan Press Ltd.

73. Mehran, H., and A. Thakor. 2011. Bank Capital and Value in the Cross-Section. The Review of Financial Studies 24 (4): 1019-1067.

74. Messai, A., and F. Jouini. 2013. Micro and Macro Determinants of Non-performing Loans. International Journal of Economics and Financial Issues 3: 852-860.

75. Ng, J., and S. Roychowdhury. 2011. Do Loan Loss Reserves Behave like Capital? Evidence from Recent Bank Failures. Review of Accounting Studies 19: 1234-1279.

76. Olszak, M., P. Chodnicka-Jaworska, I. Kowalska, and F. Świtała. 2018. The Euopean Journal of Finance 24 (17): 1672-1698.

77. Paltrinieri, A., A. Khan, and Hassan M. Kabir. 2018. Liquidity Risk, Credit Risk and Stability in Islamic and Conventional Banks. Research in International Business and Finance 48: 17-31.

78. Pasiouras, F., C. Gaganis, and C. Zopounidis. 2006. The impact of bank regulations, supervision, market structure, and bank characteristics on individual bank ratings: A cross-country analysis. Review of Quantitative Finance and Accounting 27: 403-438.

79. Petria, N., Capraru, B., Ihnatov, I. 2015. Determinants of banks' profitability: evidence from EU 27

80. Pinto, I., and W.N. Picoto. 2018. Earnings and capital management in European banks Combining a multivariate regression with a qualitative comparative analysis. Journal of Business Research 89: $258-264$
81. Radic, N. 2015. Shareholder value creation in Japanese banking. Journal of Banking and Finance 52: 199-207.

82. Rochet, J.C. 1992. Capital requirements and the behaviour of commercial banks. European Economic Review 36: 1137-1170.

83. Roy, A.D. 1952. Safety first and the holding of assets. Econometrica 20 (3): 431-449.

84. Shim, J. 2010. Capital-based regulation, portfolio risk and capital determination: Empirical evidence from the US property-liability insurers. Journal of Banking and Finance 34 (10): 2450-2461.

85. Siems, T. 2012. The So-Called Texas Ratio. Financial Insights 1 (3): $1-3$.

86. Smaga, P. 2014. The Concept of Systemic Risk. http://eprints.lse. ac.uk/61214/1/sp-5.pdf

87. Tan, Y. 2016. The impacts of risk and competition on bank profitability in China. Journal of International Financial Markets, Institutions and Money 40: 85-110.

88. Tan, Y., and C. Floros. 2013. Risk, capital and efficiency in Chinese banking. Journal of international financial Markets, Institutions and Money 26: 378-393.

89. Viale, A.M., J.W. Kolari, and D.R. Fraser. 2009. Common risk factor in bank stocks. Journal of Banking and Finance 33 (3): 464-472.

90. Vishnani, S., S. Agarwal, R. Agarwalla, and S. Gupta. 2019. Earnings Management, Capital Management and Signalling Behaviour of Indian Banks. Asia-Pacific Financial Markets 26: 285-295.

Publisher's Note Springer Nature remains neutral with regard to jurisdictional claims in published maps and institutional affiliations. 